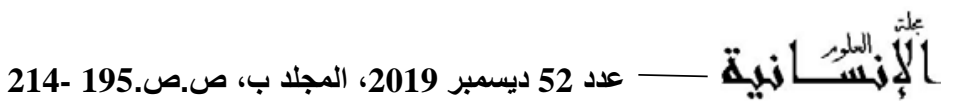

\title{
عقد الامتياز كآلية لاستغلال العقار السياحي في الجزائر
}

The concession contrat as a mechanism for the exploitation of tourist property in Algeria

تاريخ الاستلام :2019/09/21 ؛ تاريخ القبول : 2019/10/14

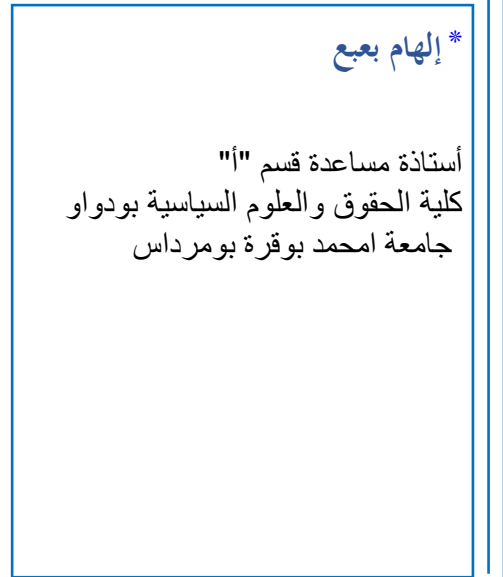

\section{Abstract}

The tourist land is one of the types of property directed to investment. In order to make it one of the pillars of economic and tourism development, the legislator has established the mode of concession as a mechanism for its exploitation.

The state's public and private property is the scope of its application. This was revealed in 2008 when the legislator approved the non- The way of the public auction as an asset and consent as an exception to the territory of the private state, finally to adopt the system of concession by mutual consent under the supplementary Finance law 2011 to encourage investors.

Keywords: Tourist land- Investment-concession contracts, concession by mutual consent, concession in public auction.

\section{Résumé}

Le foncier touristique est l'un des types de biens destinés à l'investissement .pour en fair un piliers du développement économique et touristique, le législateur a établi le mode de concession en tant que mécanisme d'exploitation.

La propriété publique et privée de l'état est l'application de celle-ci.Cela a été révélé en 2008 lorsque le législateur a approuvé la maniére dont la concession aux enchéres publique était considérée comme un actif et le consentement comme une exeption sur les terrain disponible relevant du domaine privé de l'état .Enfin ,adopter le systéme de concession gré a gré prévu par la loi de finances complémentaire 2011 pour encourager les investisseurs.

Mots clés: Foncier touristique, investissement, les contrats de concession,,régle gré a gré,,régle d'enchére,.

* Corresponding author, e-mail: baba.ilhem1980@gmail.com 


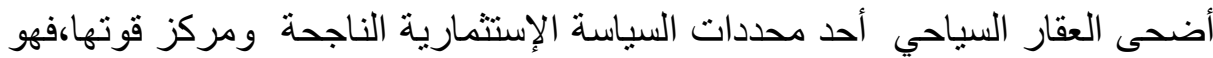

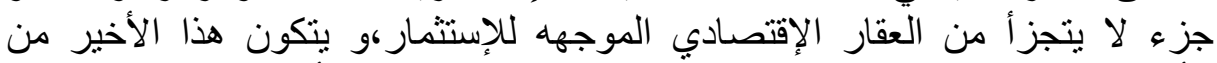

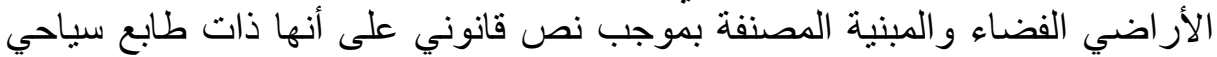

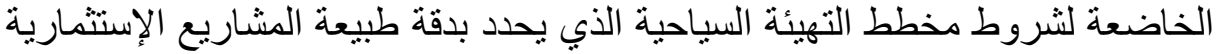

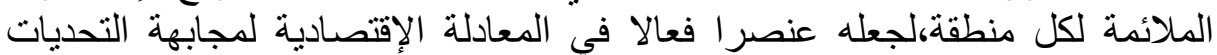

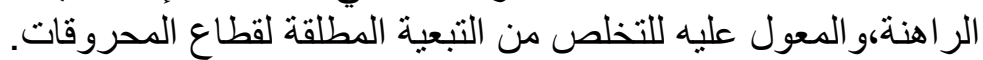

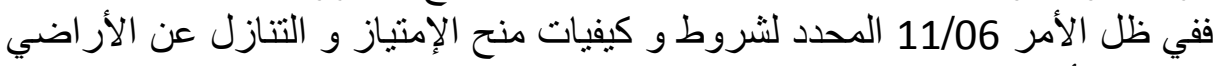

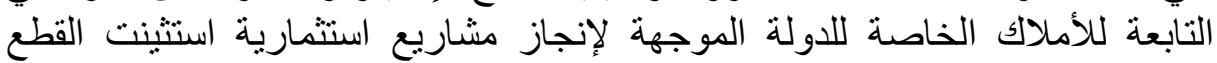

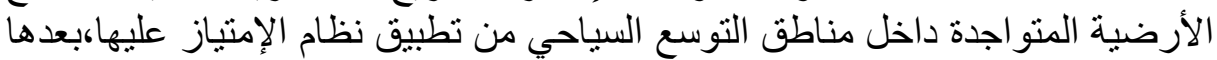

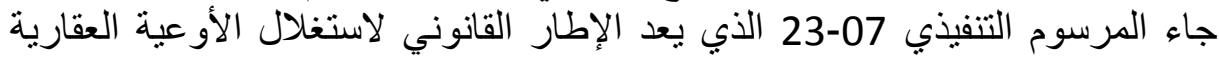

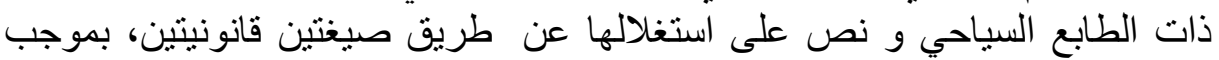

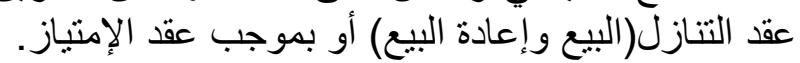

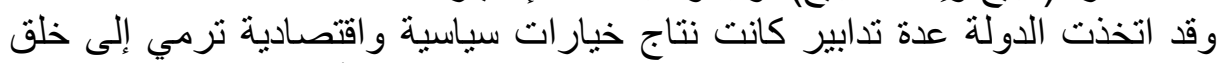

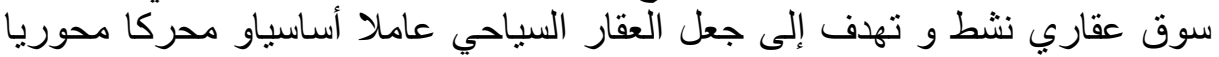

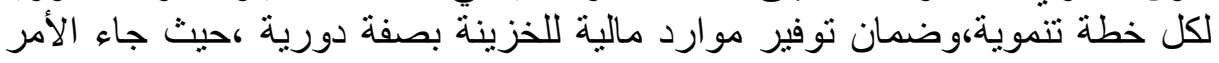

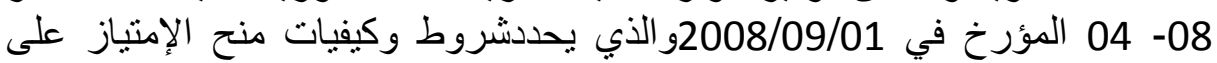

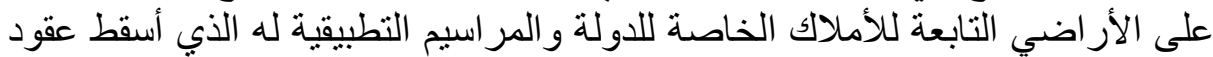

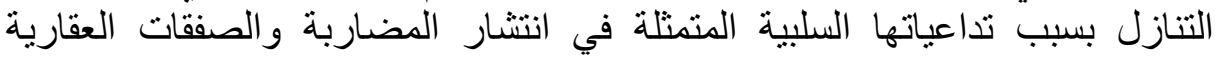

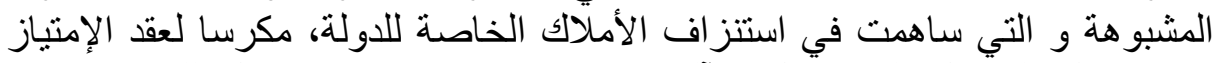

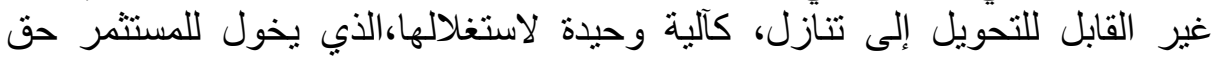

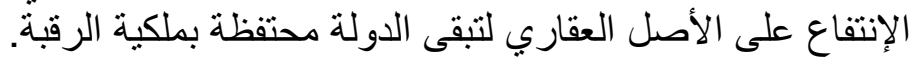

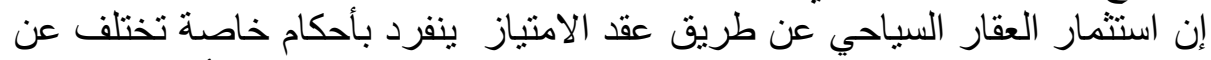

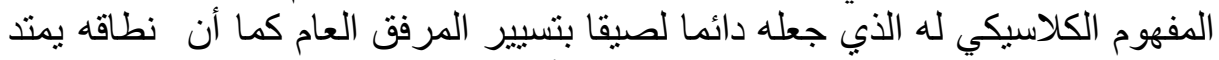

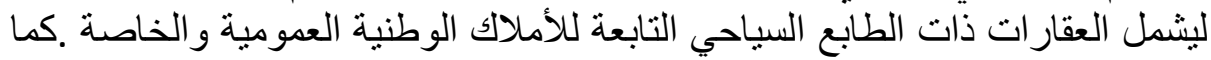

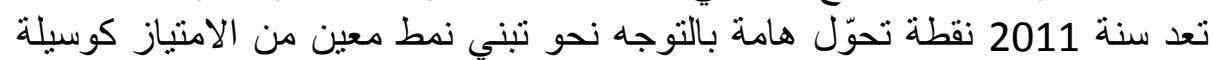

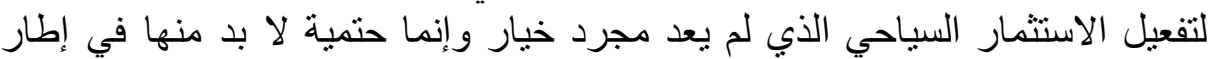

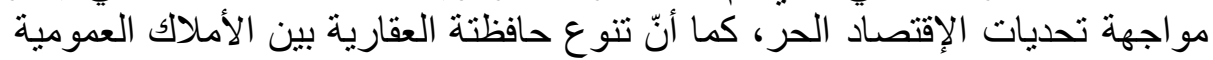

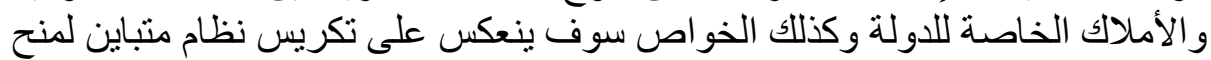

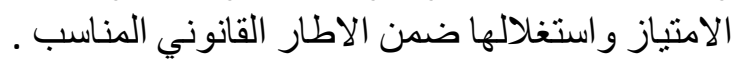
و عليه فالإشكالية التي تطر ح نفسها في ظلّ كل هذه الإن المعطيات:

ما هي السياسة التي انتهجها المشرع في منح عقود الإمتياز على العقار

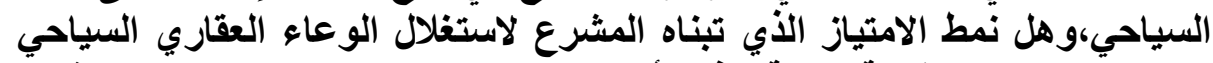

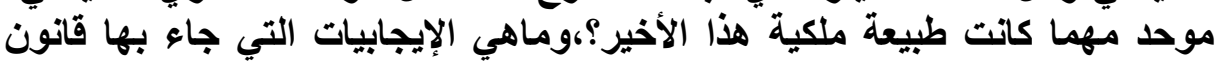

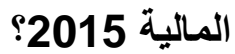

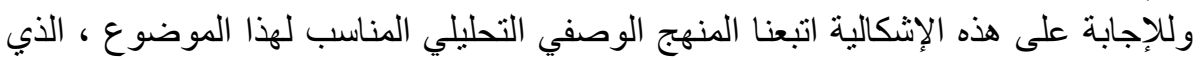

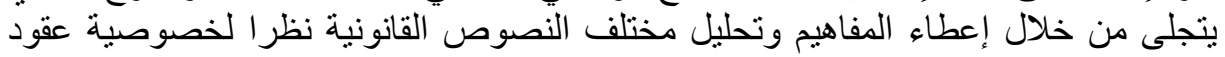

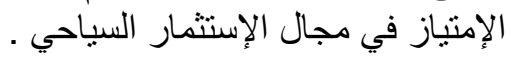
وقد قسمنا الموضو الإل إلى مبحثين: نتناول في المبحث الأول :الإطار القانوني لمنح الإمتياز على العقار السياحي

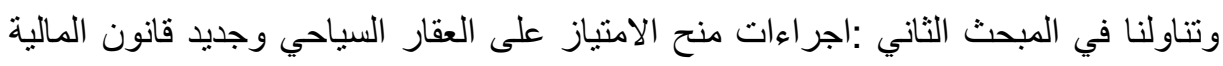
التكميلي 2015. 
المبحث الأول : الإطار القانوني لمنح الامتياز على العقار السياحي

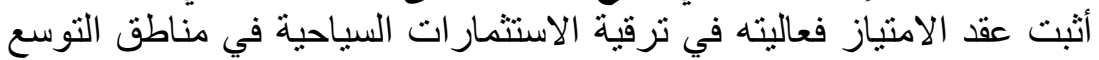

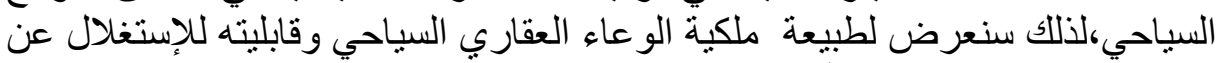

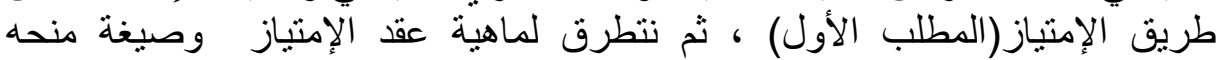

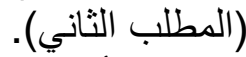
المطلب الأول : طبيعة ملكية الوعاء العقاري السياحي وقابليته للاستغلال عن طريق الامتياز

تعرف مناطق التوسع السياحي بأنها كل منطقة أو امتداد من الإقليم يتميز

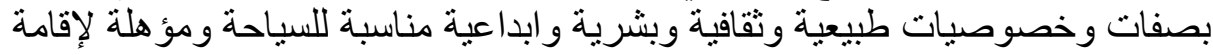

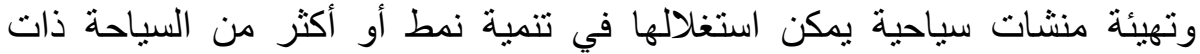

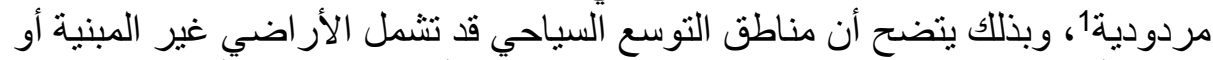

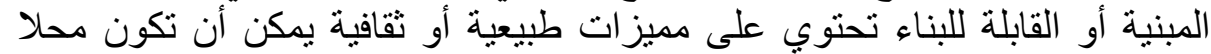

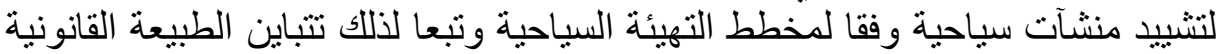

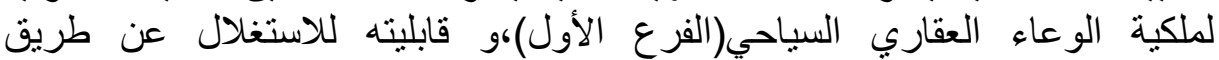

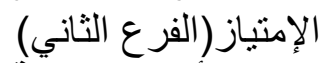
الفرع الأول : الطبيعةالقانونية لملكية الوعاء العقانة العقاري السياحي:

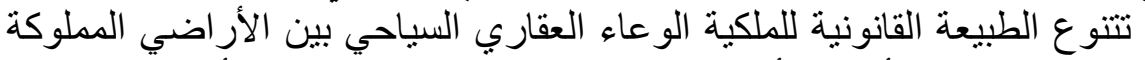

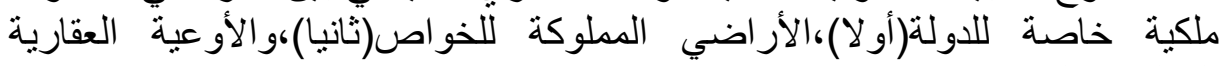

\section{المملوكة ملكية عامة للاولة لأثالثا).}

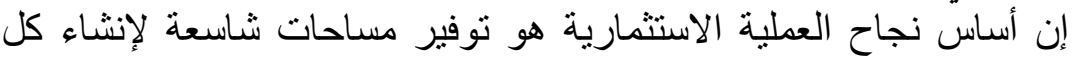

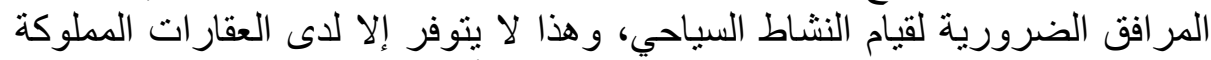

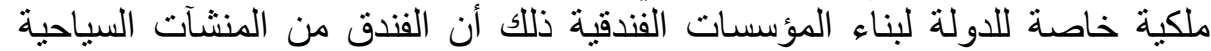

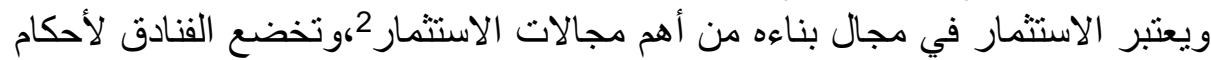

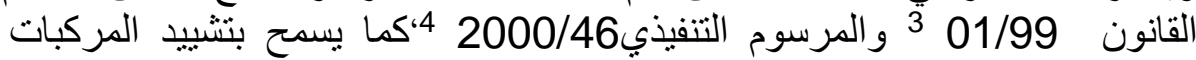

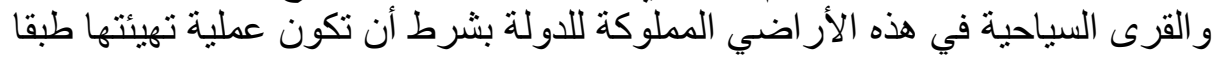

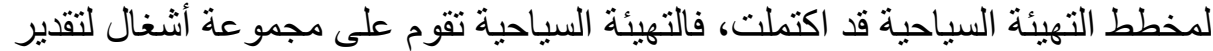

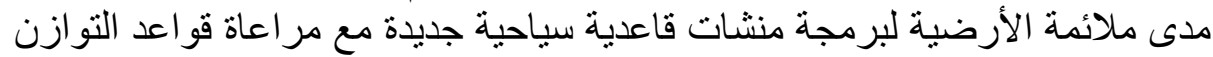

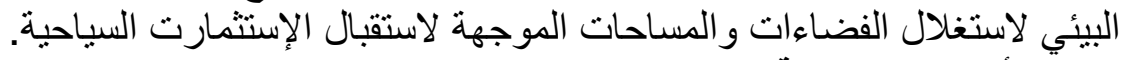

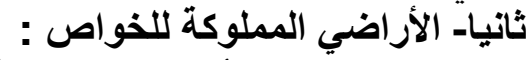

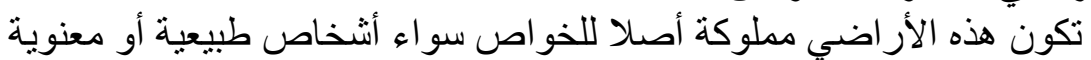

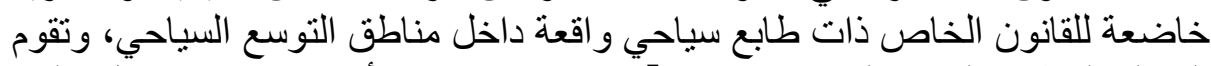

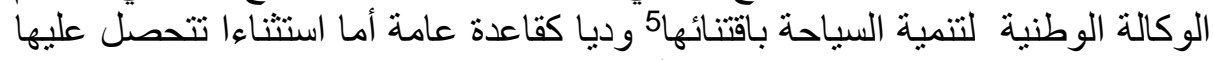

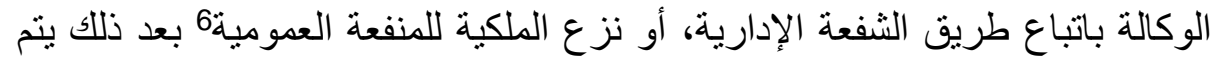

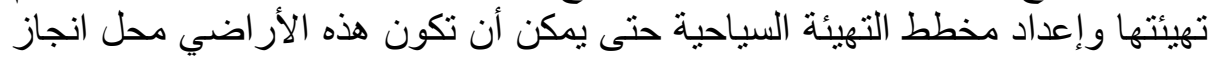
مشاريع سياحية.

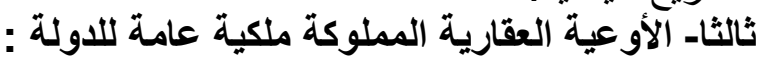

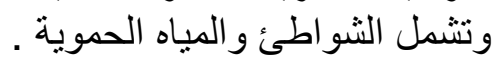

$$
1
$$

يعتبر الثاطئ جزء عا من مناطق التوسع السياحي تتمركز فيه السياحة

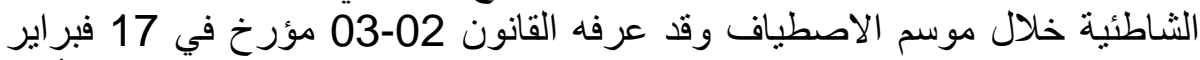

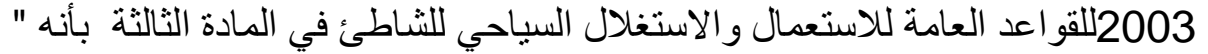

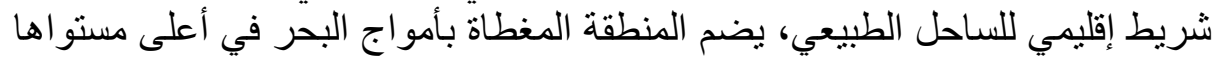

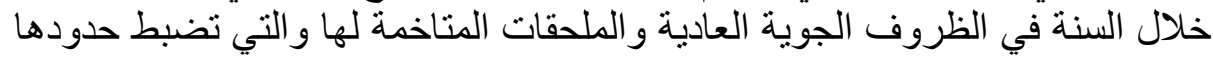
بحكم موقعها وقابليتها السياحية لاستقبال بعض ولئ المنشآت بغرض استغلالكها". 
كما عرفه المرسوم التنفيذي 12/427 7 المحدد لإدارة وتسيير الأملاك العمومية

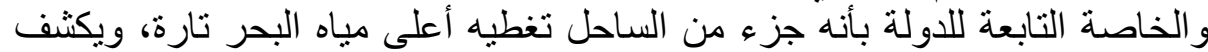

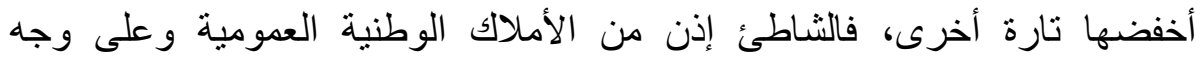

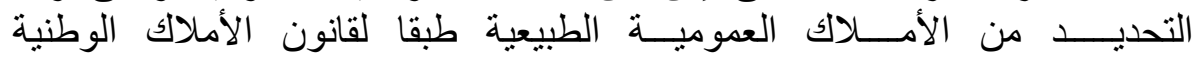

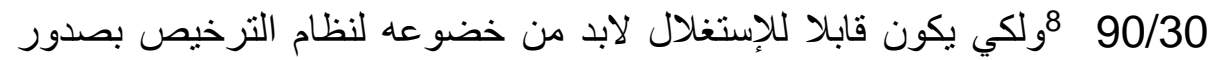

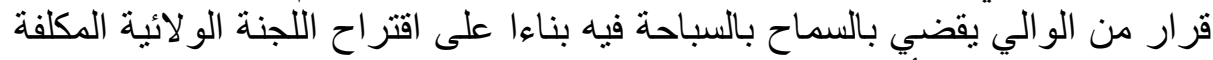

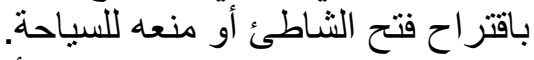
ويشترط للبدء في استغلاله أن يكون جاهن النها والنه و مهيئا طبقا لمخطط التهيئة

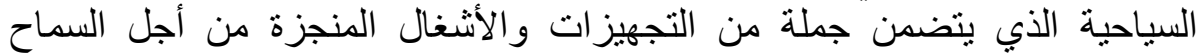

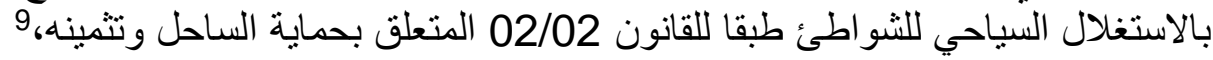

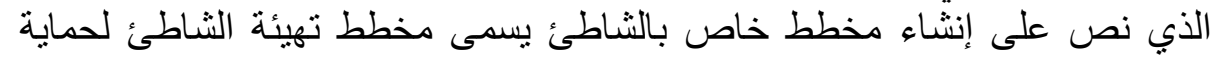
الفضاءات الثاطئية لاسيما الحساسة منها يتضمن جميع الأحكام و القو انين و التنظيمات

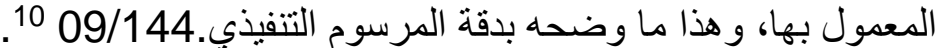
2

تعد المياه الحموية شكلا من أثنكال العقار السياحي ،وبالضبط جزء الها من مناطق

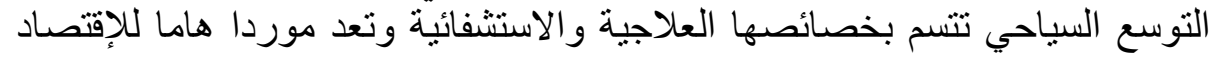

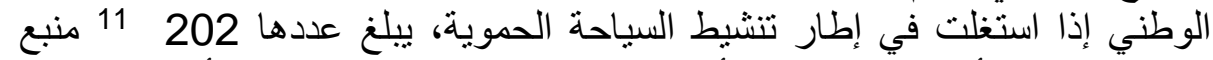

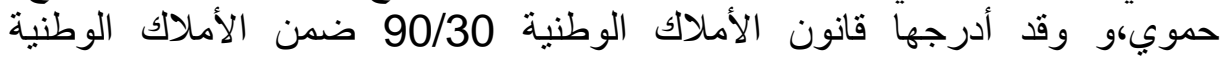

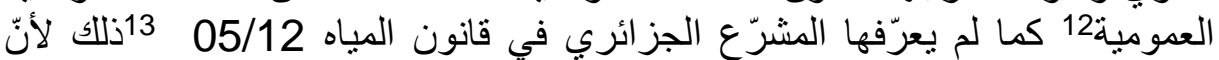
المشرع قد حدد بموجب هذا القانون القواعد العامة لحماية المياه وكيفية تسيرها

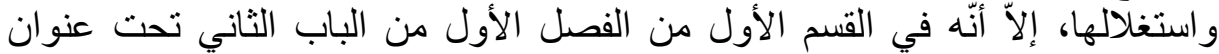

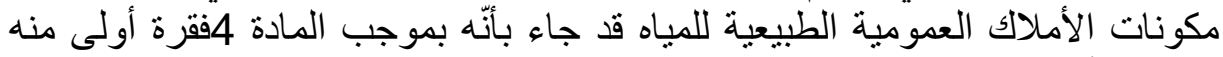

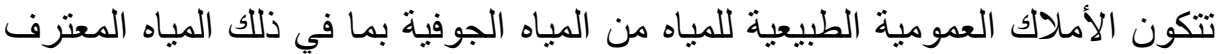

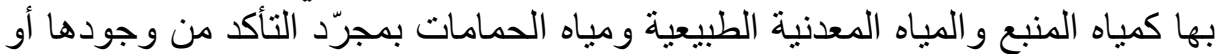

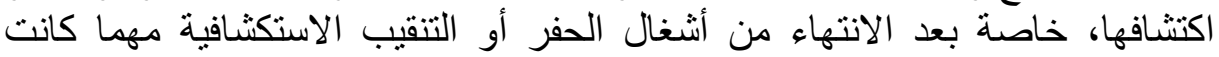

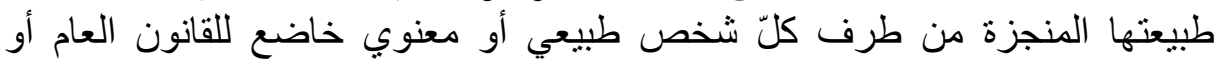

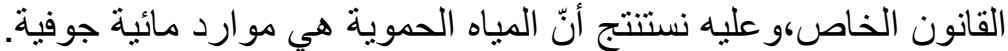

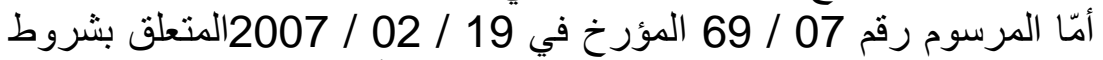

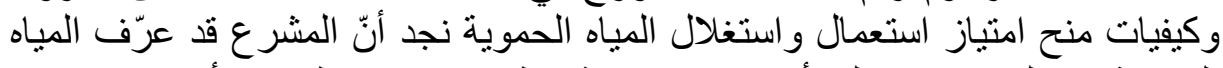

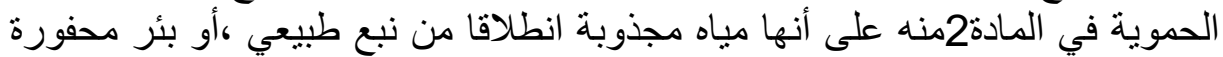

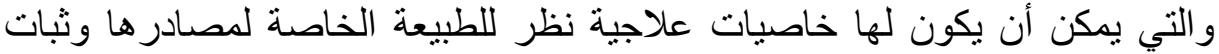

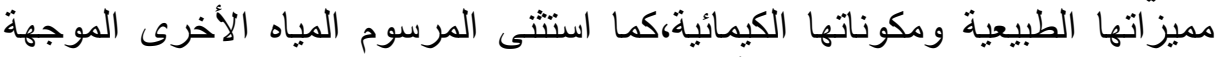

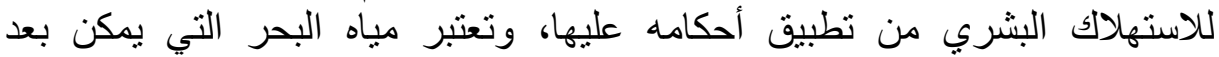

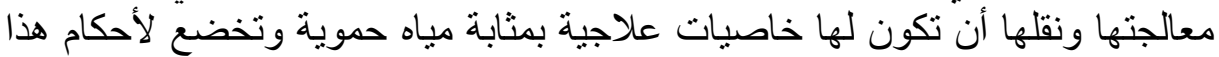

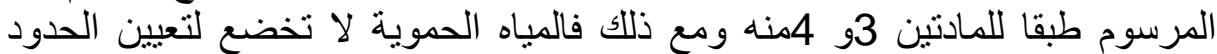

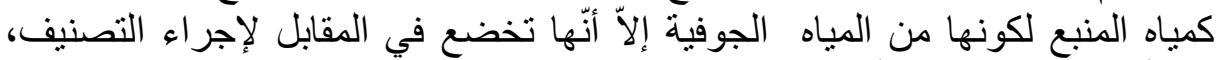

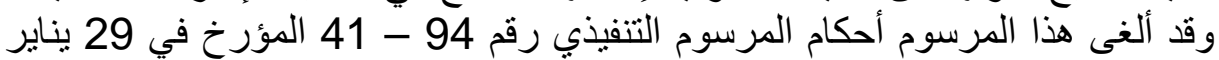
1994 المتضمن تعريف مياه الحمامات المعدنية وتنظيم حمايتها واستغلالها

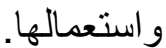
و لأجل تفعيل دور الحمامات المعدنية واستغلالها سياحيًا في إطار ترقية السياحة

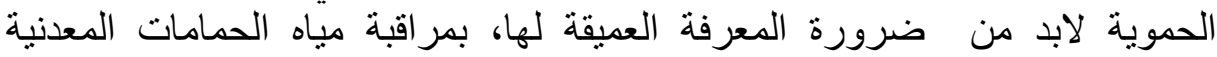

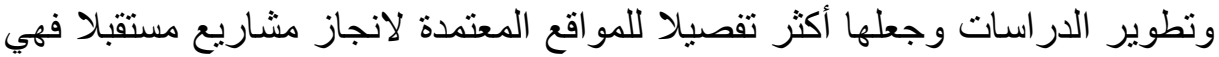

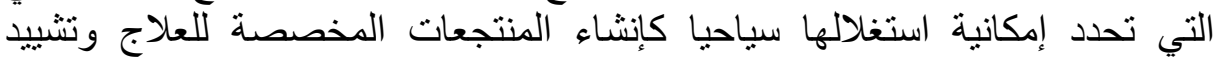


الفنادق وتهيئتها طبقا للشروط البيئية 14.

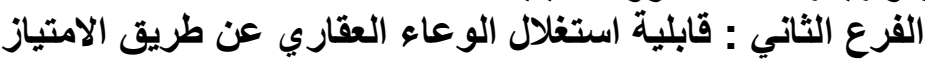

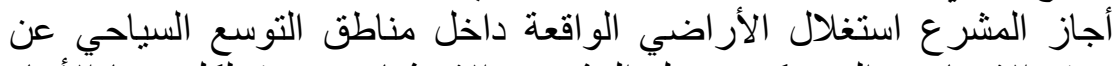

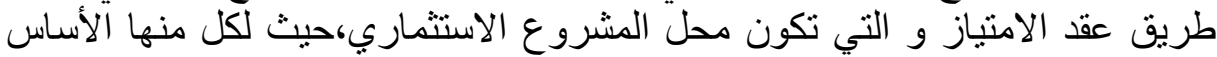

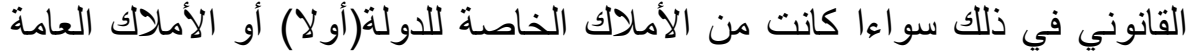

أولا- الأساس القانوني في منح الامتياز على الأملاك الخاصة للاولة : لإنة

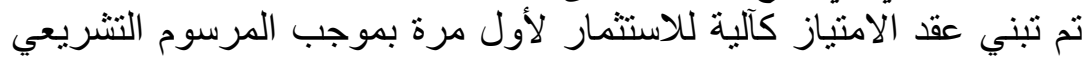

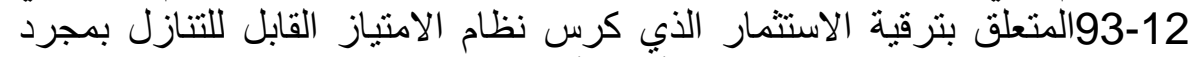

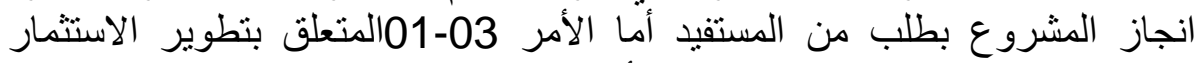

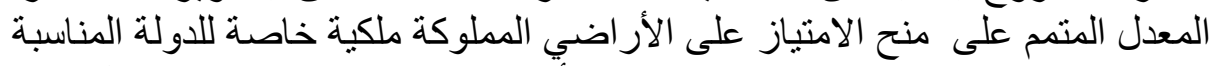

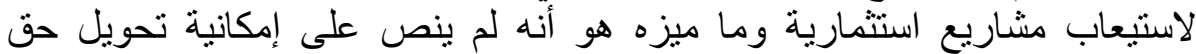

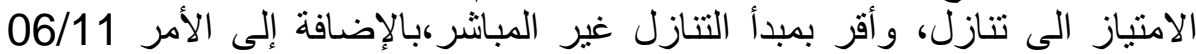

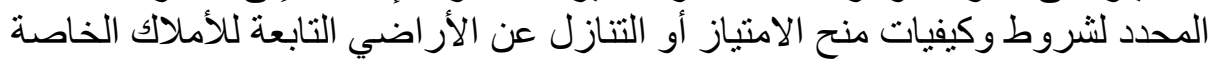

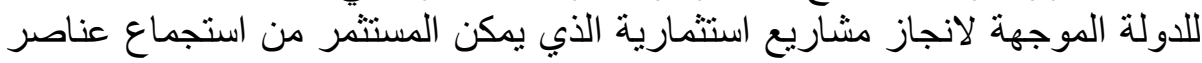

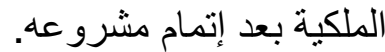

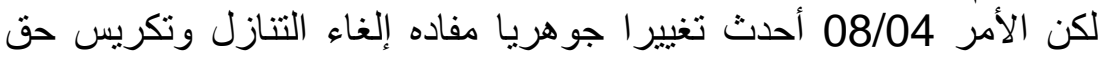

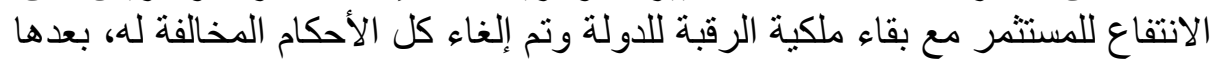

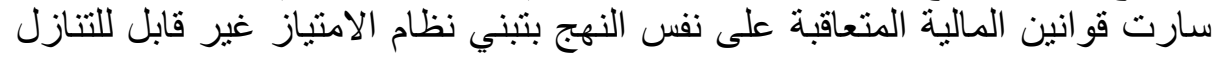

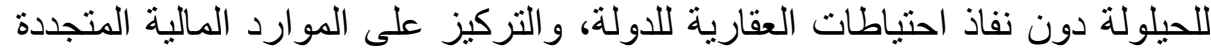
الناتجة عن إمكانية تجديد عقد الامتياز

ثانيا -الأساس القانونة تُني في منح الامتياز على الأملانك العامة لدولة:

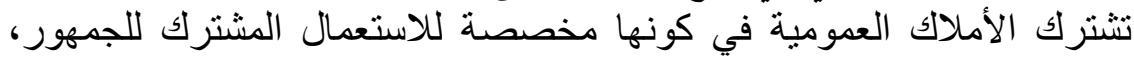

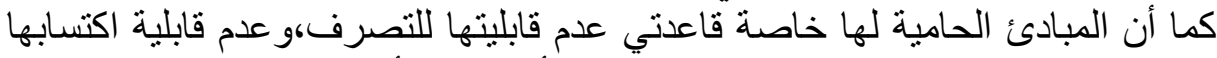

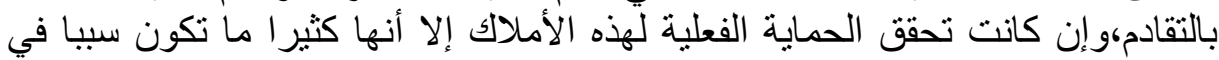

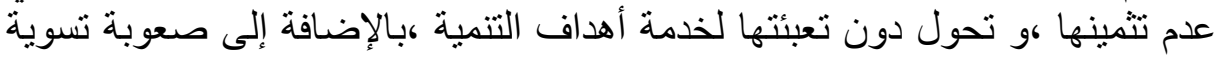

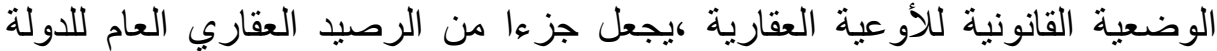

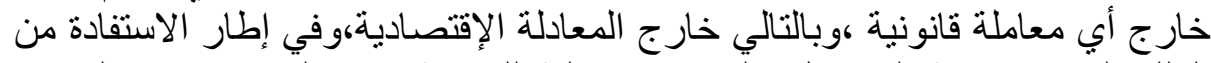

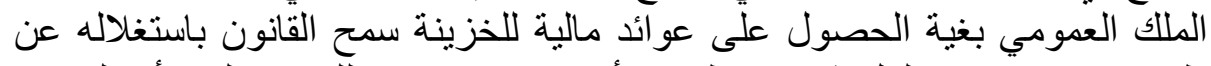

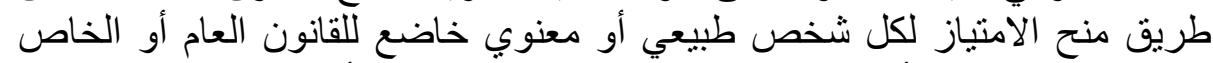

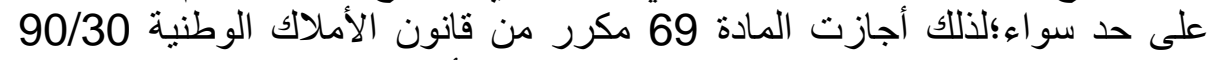

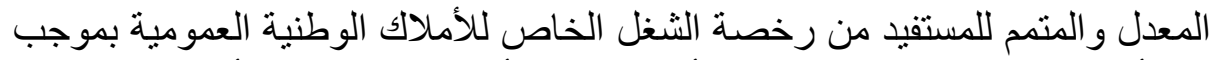

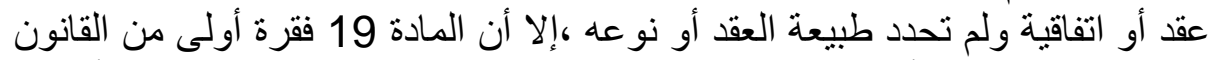

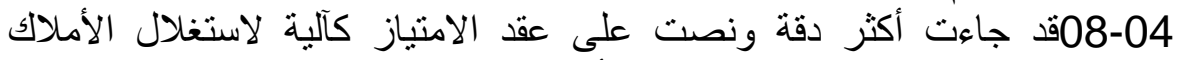

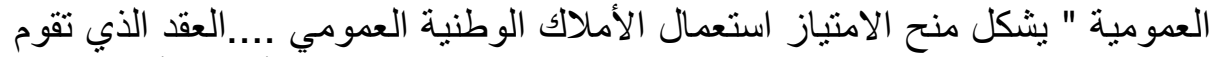

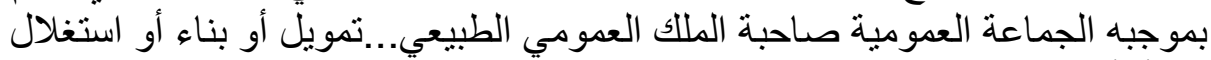

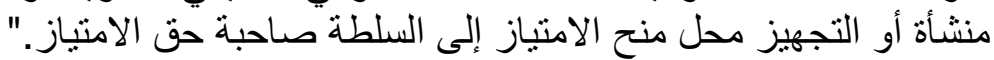

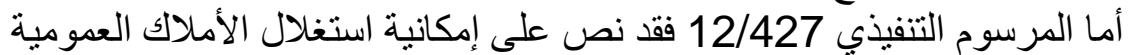

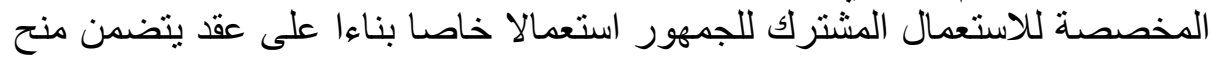

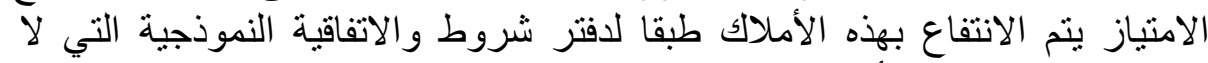

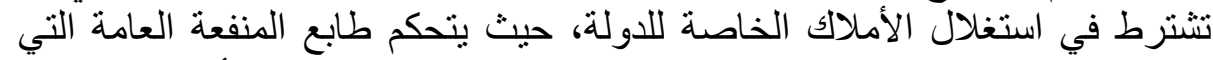

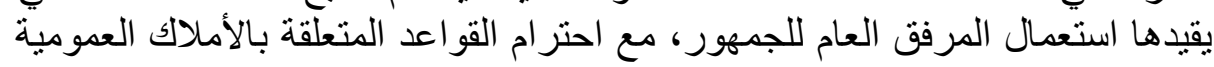

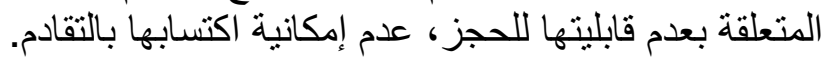

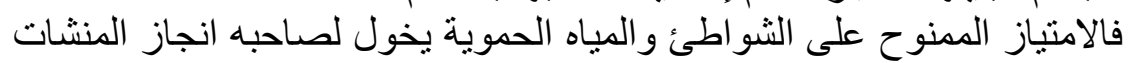

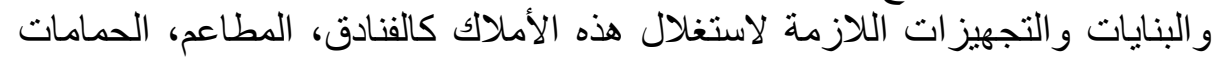


الاستشفائية، المنتجعات والمركبات السياحية، وكأصل عام يتم منح حق الاتنفاع لمدة

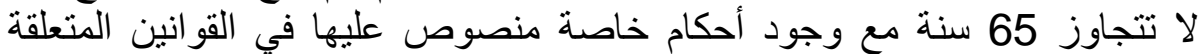

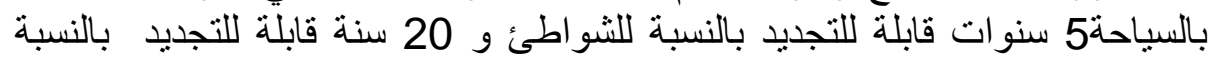
للمياه الحموية،ون مناطق التوسع التوانة السياحي. المطلب الثاني: ماهية عقد الامتياز وصيغة منحه التياه

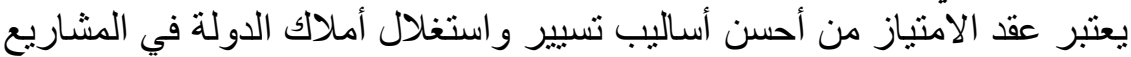

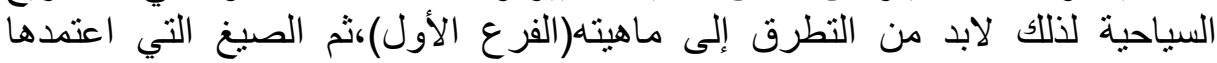
المشرع في منحهاه(الفرع الثاني). الفرع الأول: ماهية عقد الامتياز

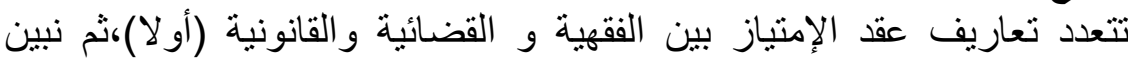

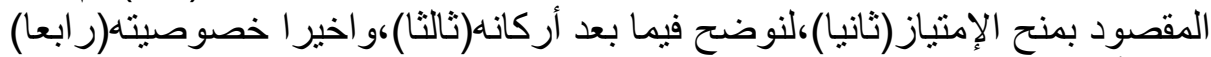
أولا:تعريف عقد الإمتياز تختلف تعاريف عقد الإمنياز بين الفقهية و القضائية والقانونية.

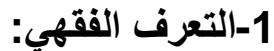

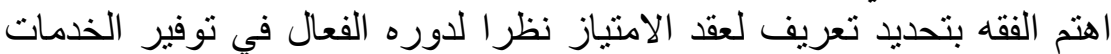

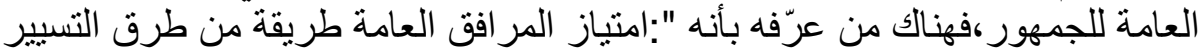

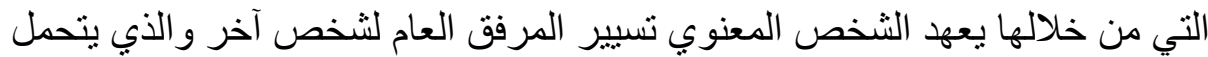
مخاطره وفو ائده مقابل استثمار المرفق العن العام 15.

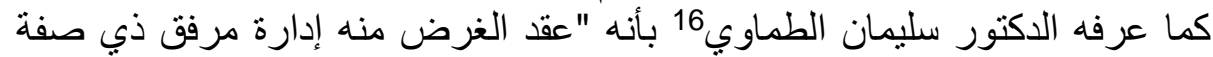
اقتصادية، ويكون هذا العقد بين جهة الإدارة المختصة وبين الطين فرد أو شركة يعهد إليها

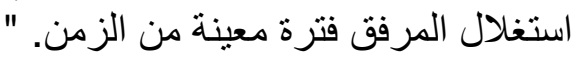

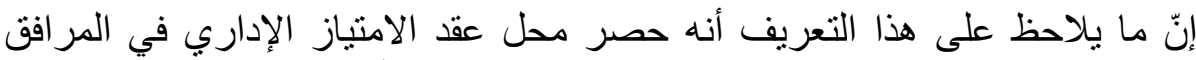

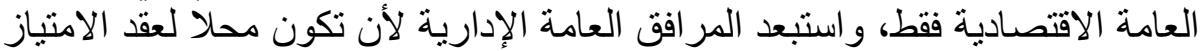

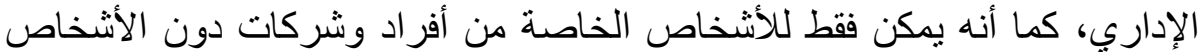

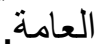

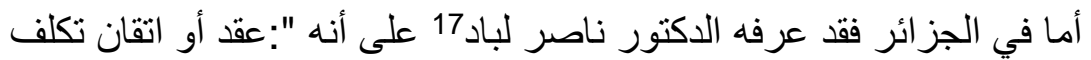

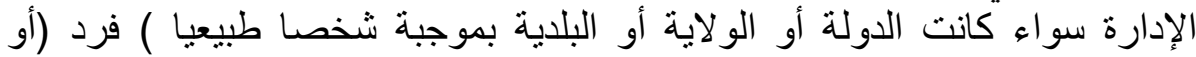

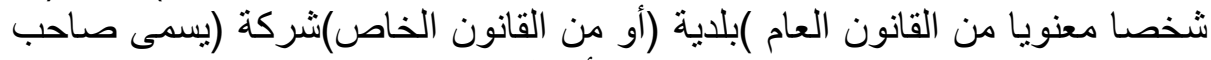

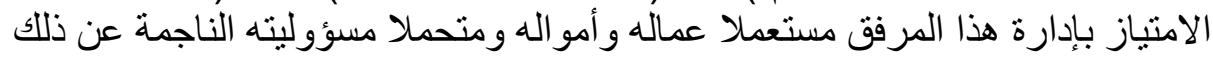

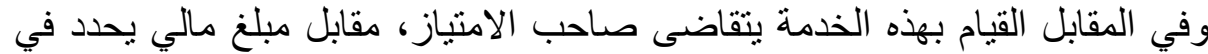
العقد يدفعه المنتفعون بخدمات المرفق"، ما يلاحظ على هذا التعريف أنهافي أنه ألم بكل

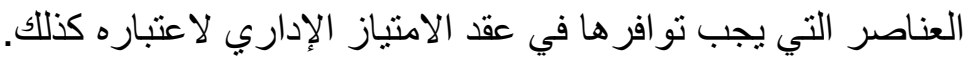

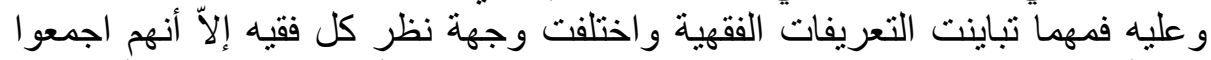

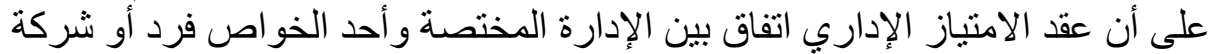

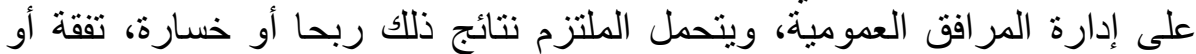

أما القضاء18 فقد عرف عقد الامتياز بموجب قرار صائ صادر عن مجلس الدولة

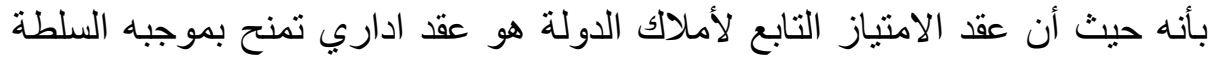

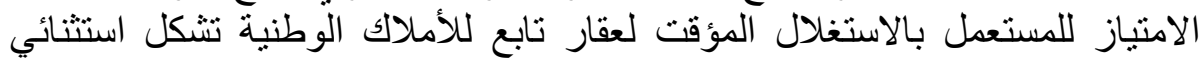

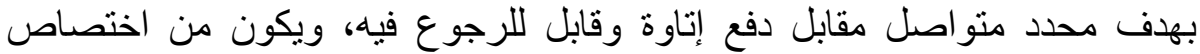

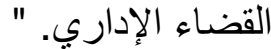
إنّ هذا التعريف أكثر دقة ذلك أن الامتياز هو الاتفاق الذي تخول من خلاله الدولة حق 
عني عقاري ناتج عن عقد الامتيازيتمثل في حق الإنتفاع،ولقد نظمت قو انين الاستثمار

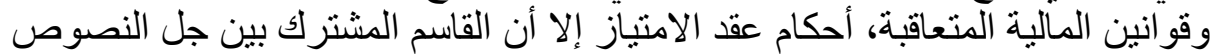

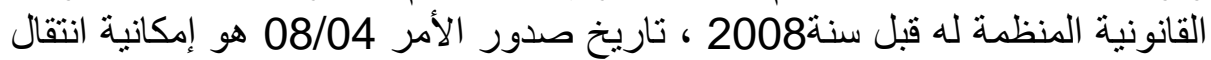

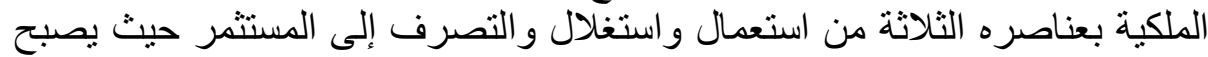

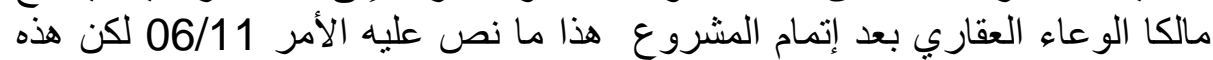

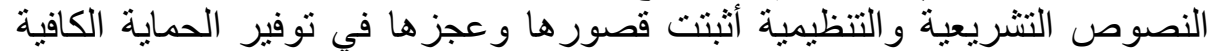

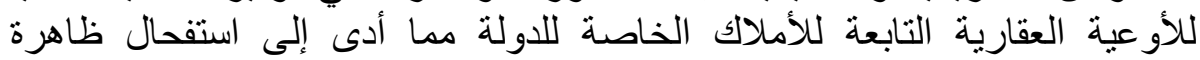

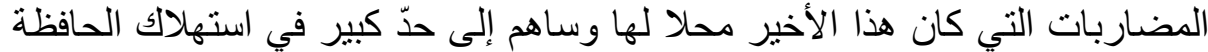

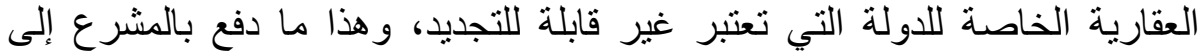

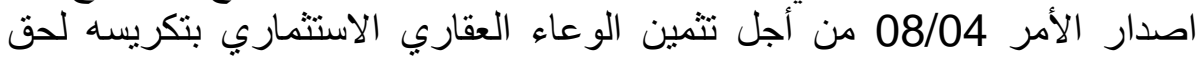

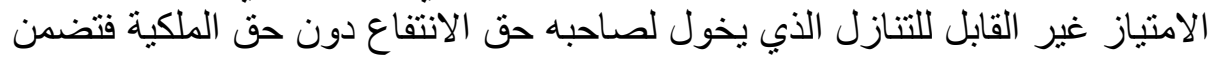

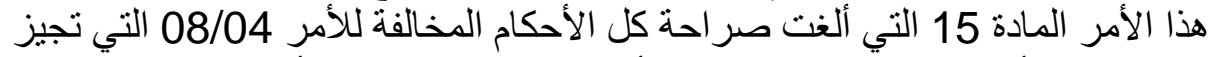

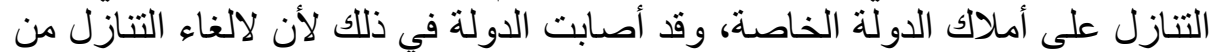

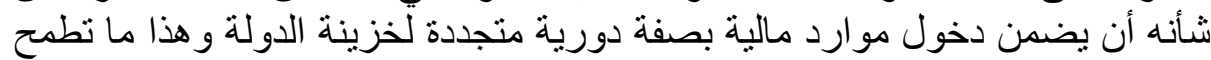

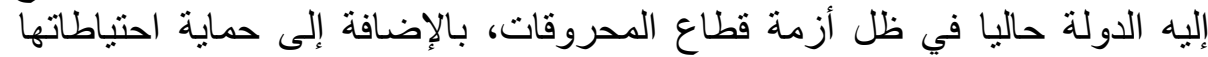

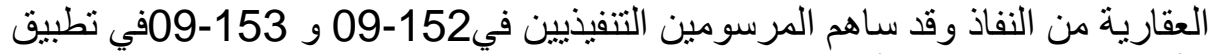

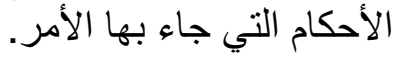

ثانيا- تعريف منح الامتياز:

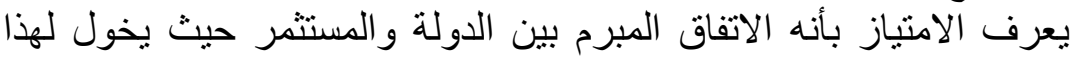

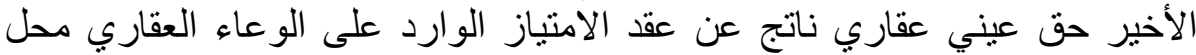

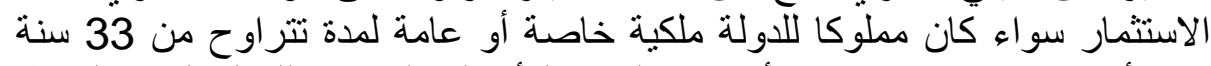

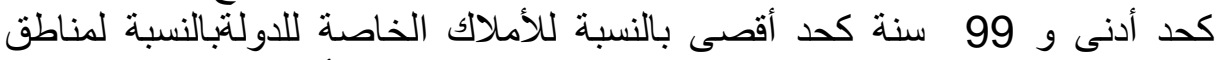

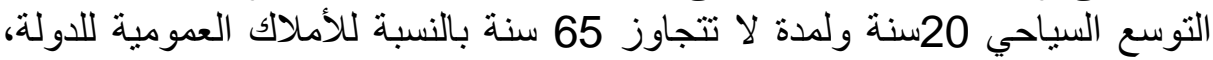

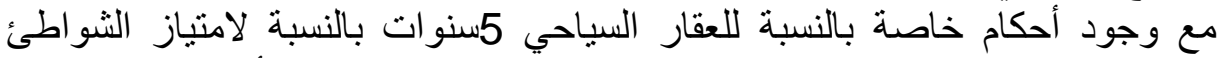

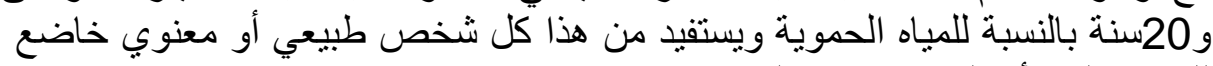

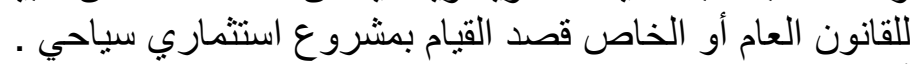

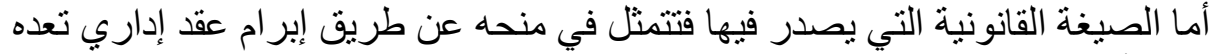

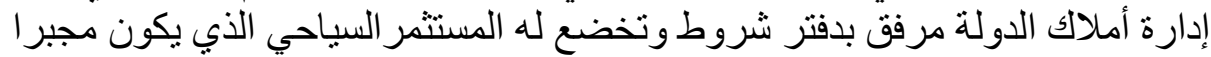

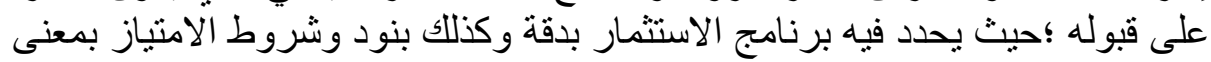

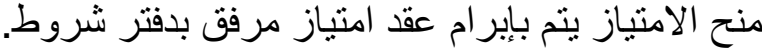

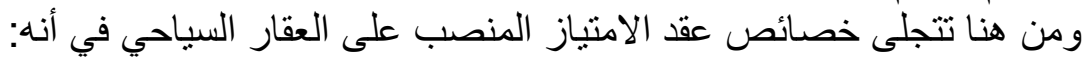

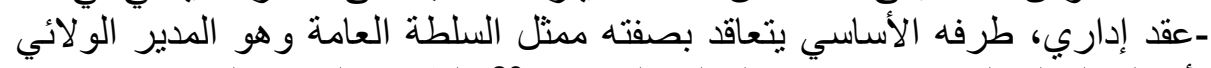

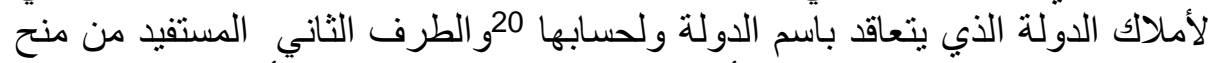

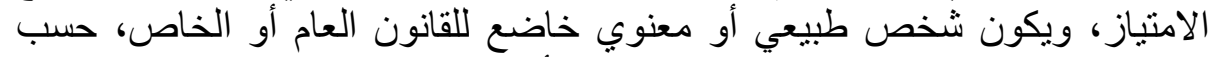

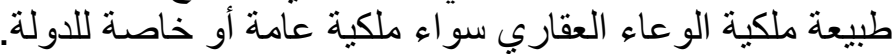

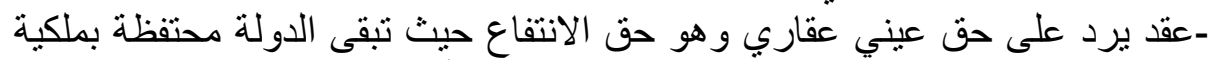

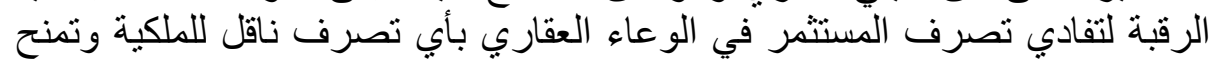

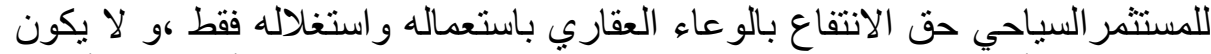

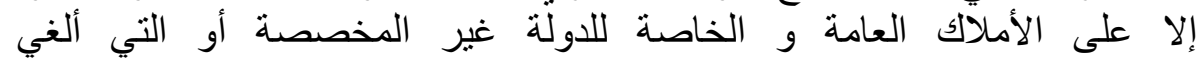

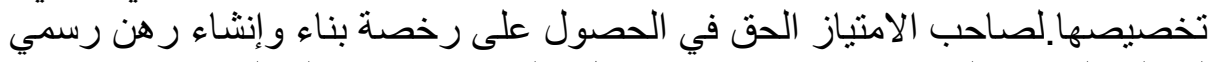

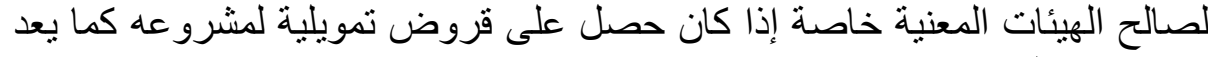

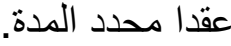
ثنالثاء أركان عقد الامتياز السياحي:

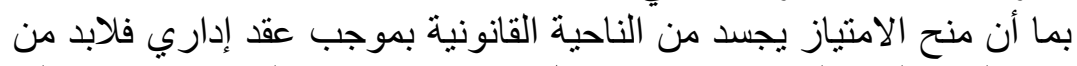
تو افر الأركان العامة لقيام العقد من رضا ومحل وسبب بالإضافة إلى كونه عقد شكلي 
بمعنى عدم احترام الإجراءات الثكلية في إبرامه يؤدي إلى بطلانه وسنوجز هذه

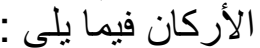

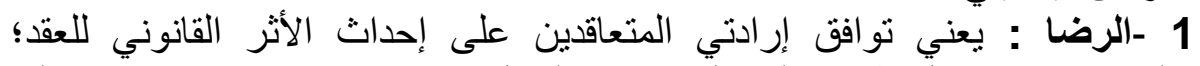

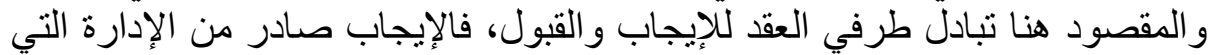

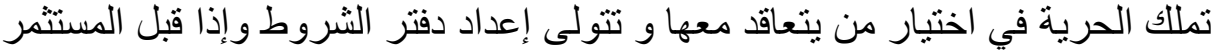

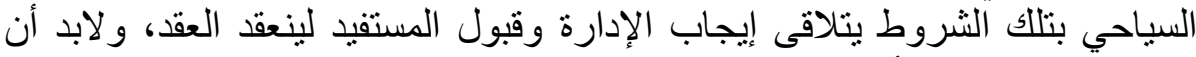

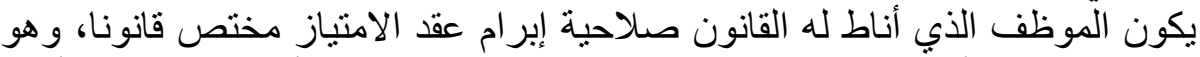

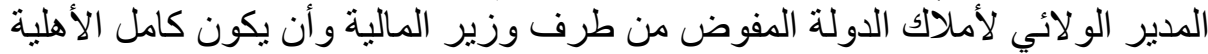

طبقالما نص عليه القانون المدني( المادة 40 منه).

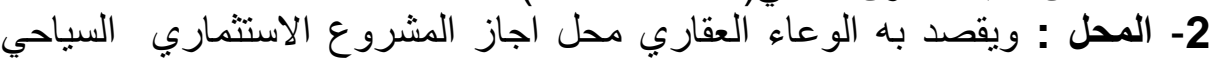

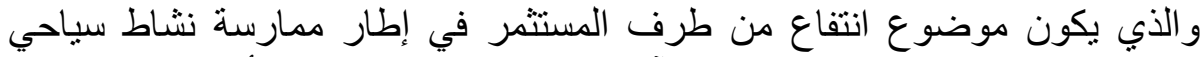

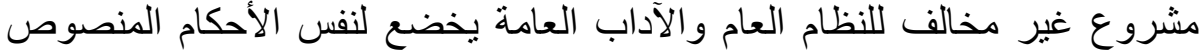

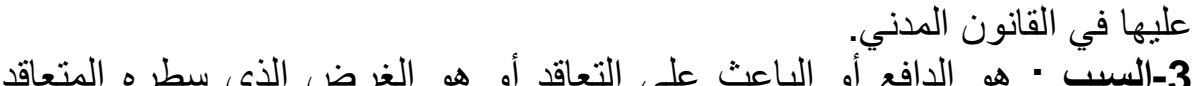

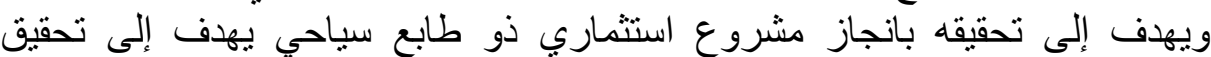

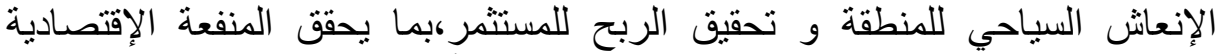

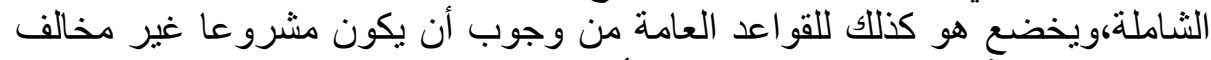

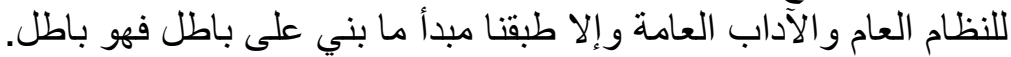

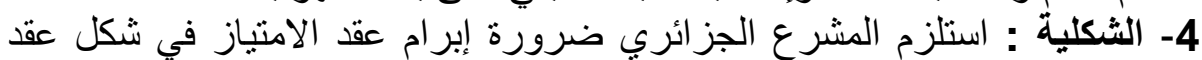

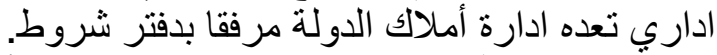

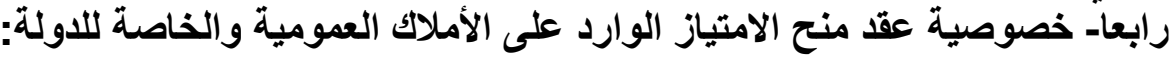

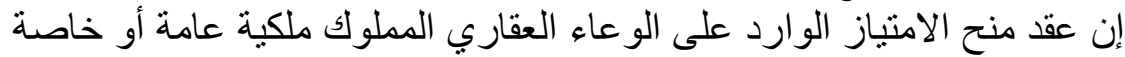

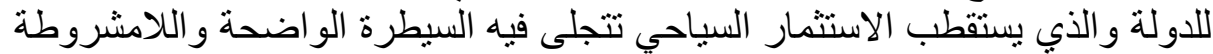

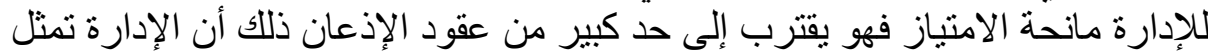

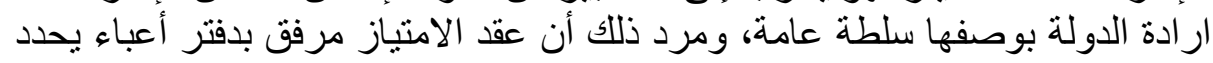

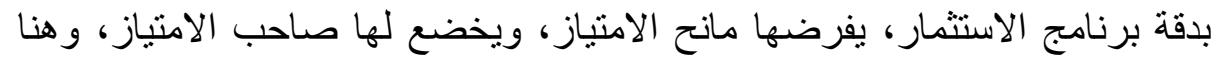

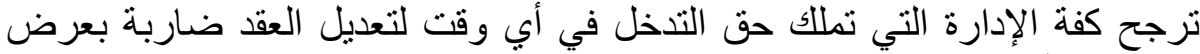

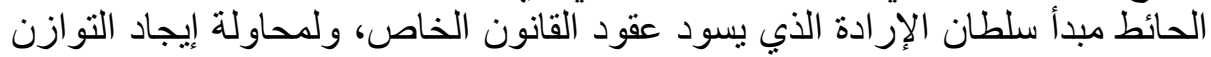

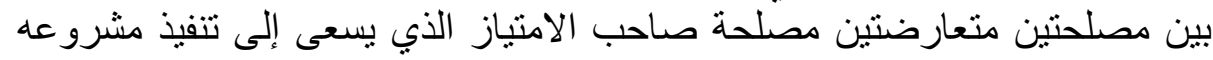

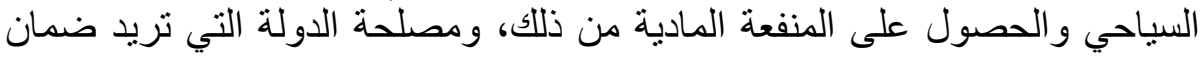

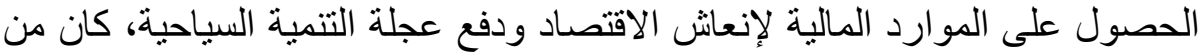

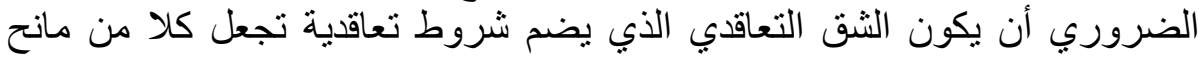

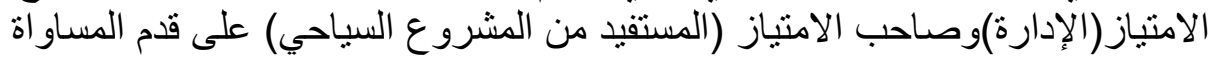

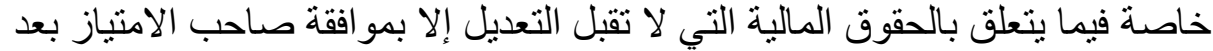
تفاوضه مع الإدارة مانحة الامتياز

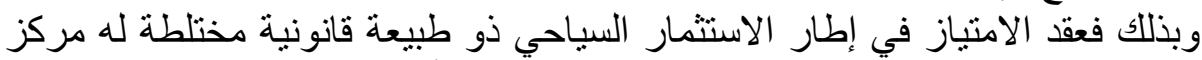

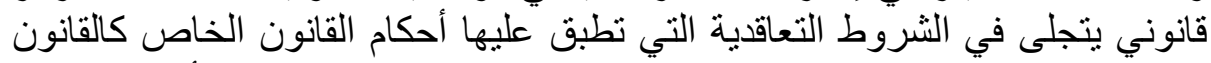

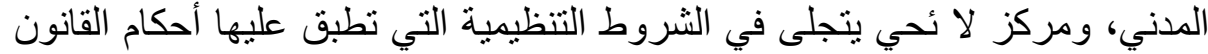

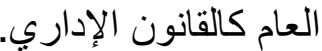

\section{الفرع الثاني : صيغة منح الامنياز الإن السياحي}

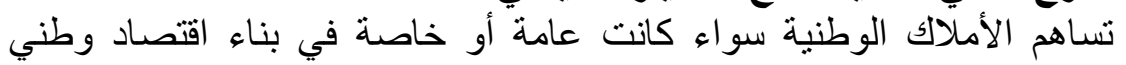

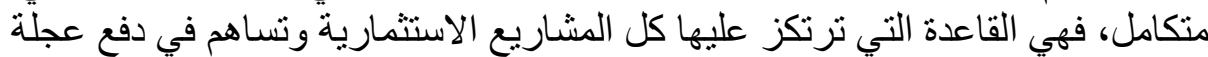
النمو الاقتصادي والاجتماعي لذلك نجد سياسة الدولة في الأخذ بنمط معين بالامتياز 
تتأرجح بين منحه عن طريق المزاد العلني أو منحه عن طريق التراضي والحد الفاصل بينهما هو قانون المالية التكميلي لسنة 201،لذلك نميز بين صيغة التين منح الإمتياز

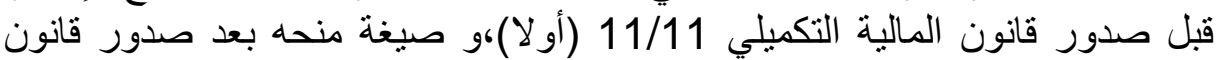

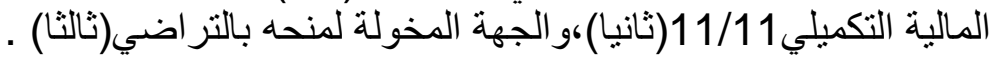
أولا- صيغة منح الامتياز قبل صدور قانون الانيان المالية التكميلي111 /11:

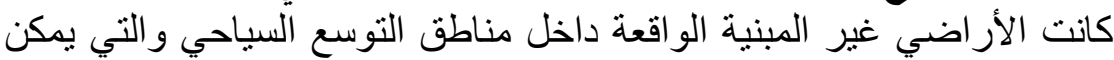

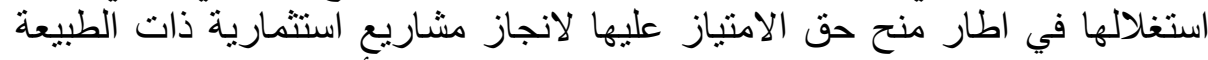

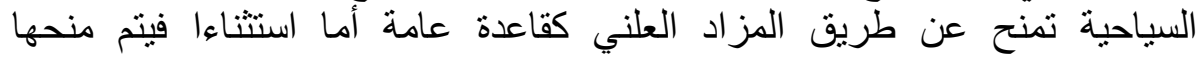

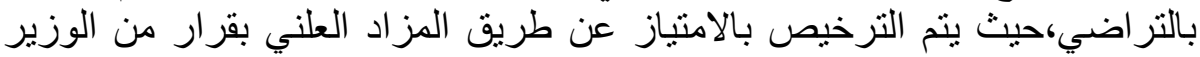

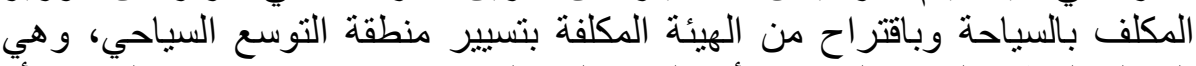

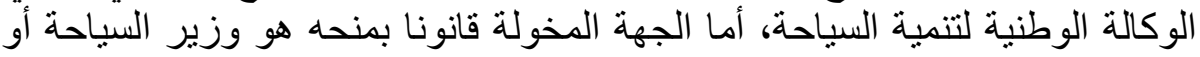

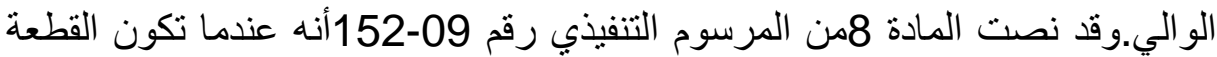
الأرضية التابعة للدولة موجودة داخل محيط منطقة التوسع السياحي يرخص التون الإمنياز

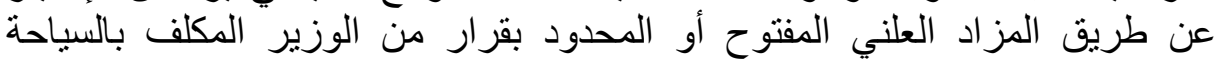

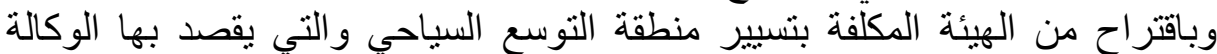

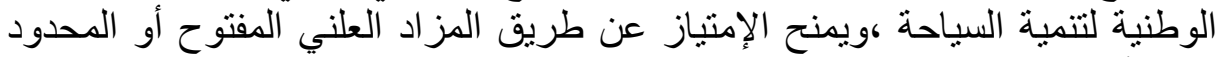

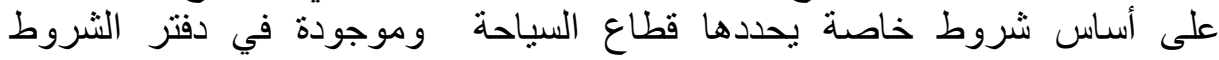

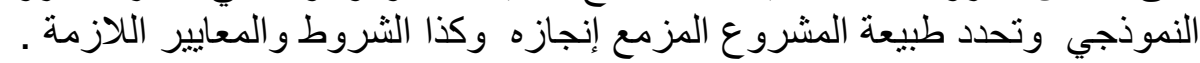

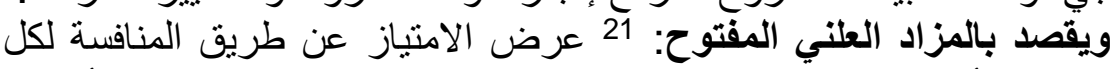

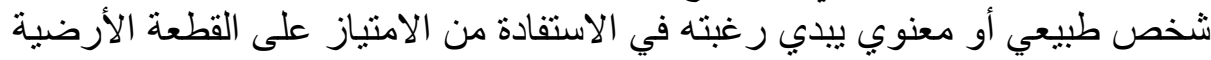

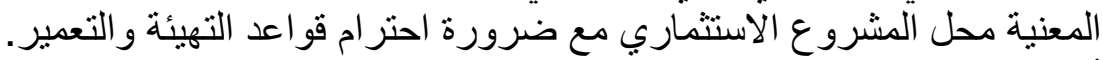

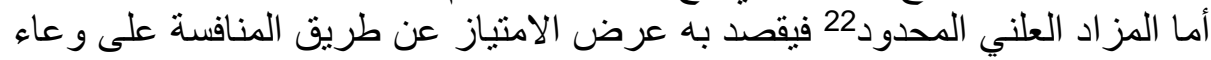

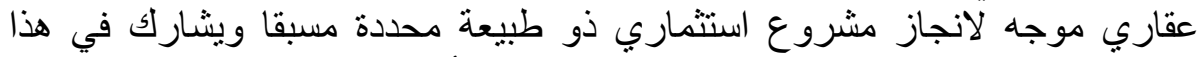

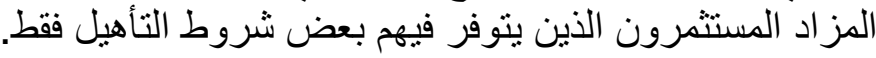

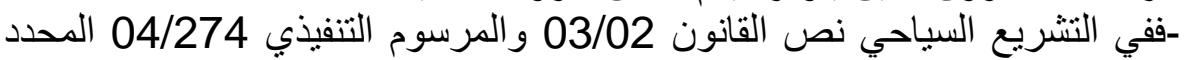

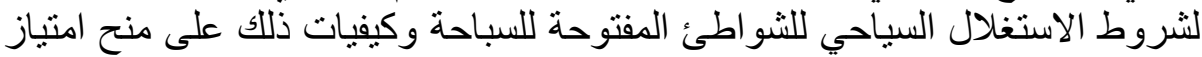

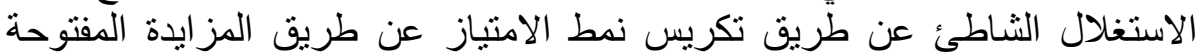

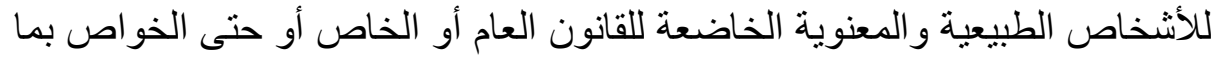

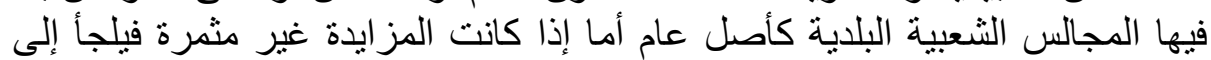

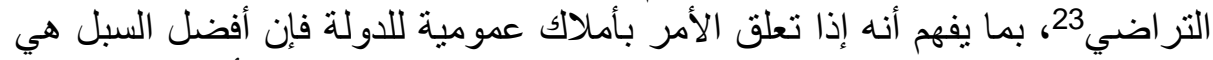

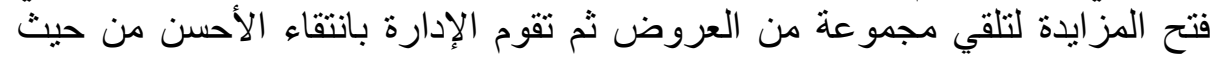

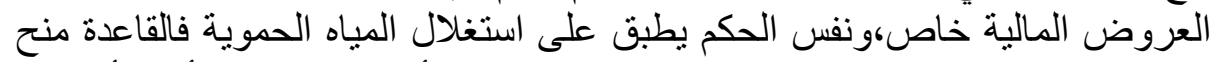

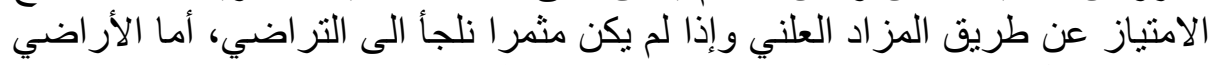

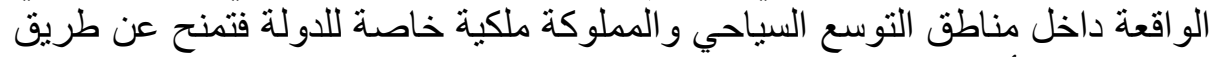

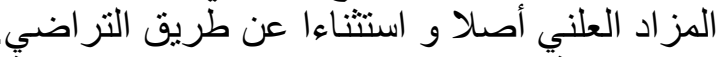

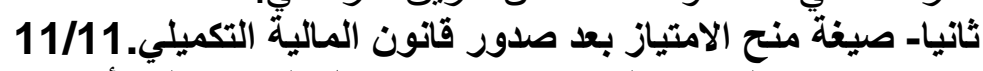

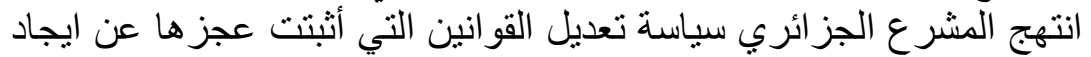

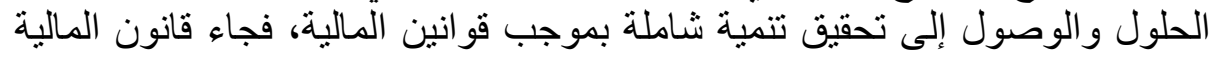

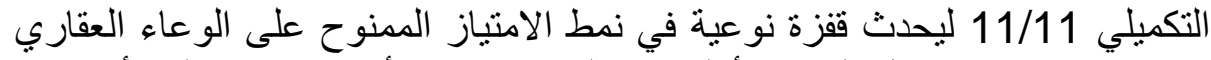

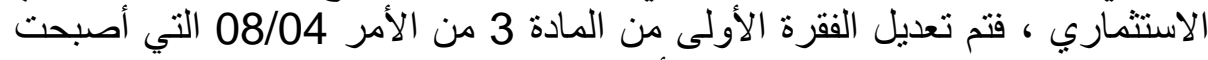

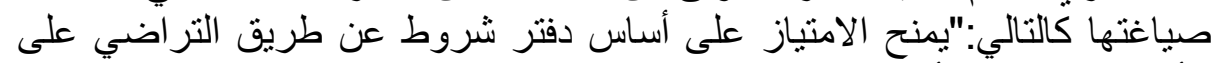

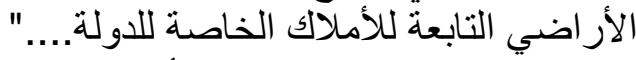

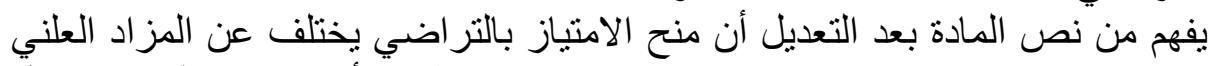

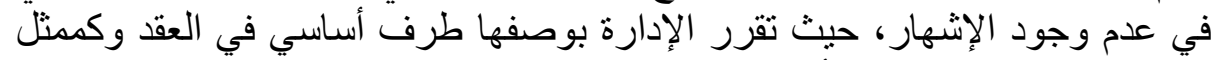
عن السلطة العامة، اختيار أفضل العروض الأف المقدمة من المستثمر خاصنة المالية منها، 
وكذا القانونية والتقنية، التي تحمل الإدارة المتعاقدة على ابر ام الصفقة معهد والتي تكون

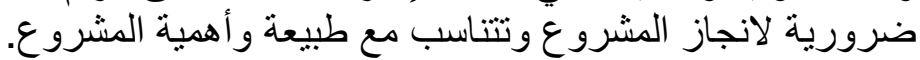

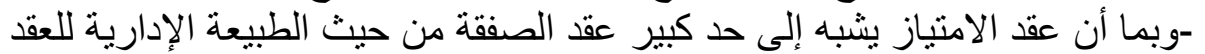

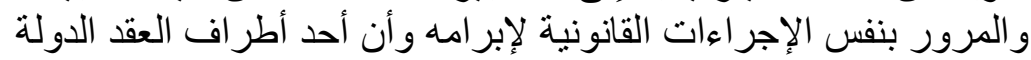

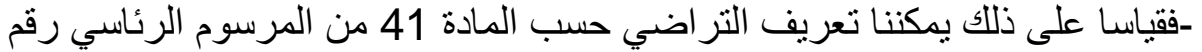

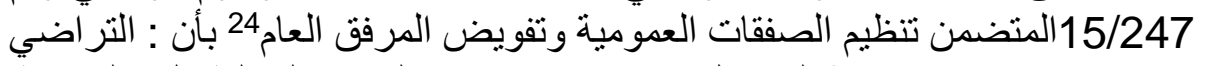

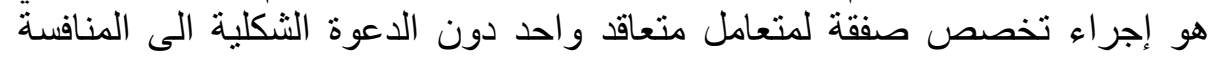

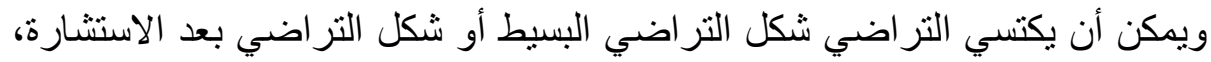
وتنظم هذه الاستشارة بكل الوسائل الملائمة.

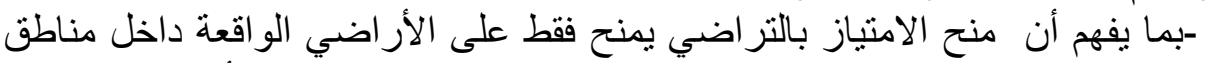

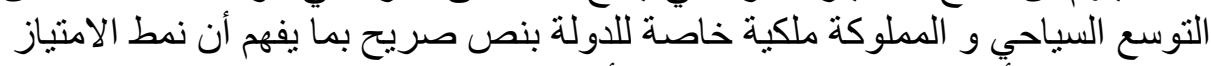

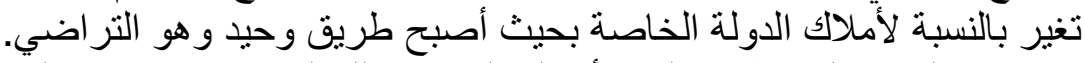

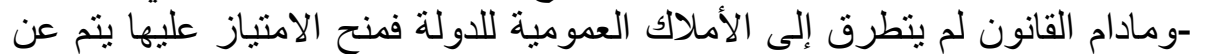

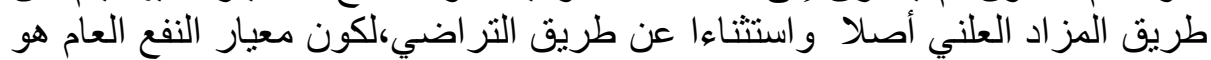

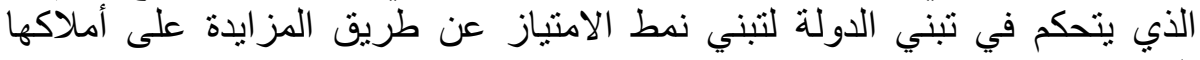

ثالثاـ الجهة المخولة لمنح الامتياز بالتراضي:

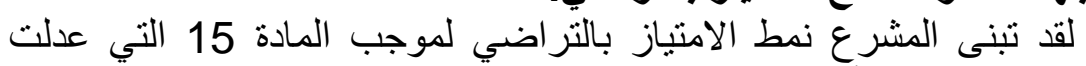

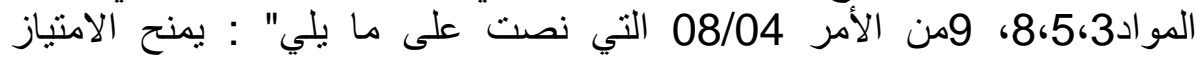

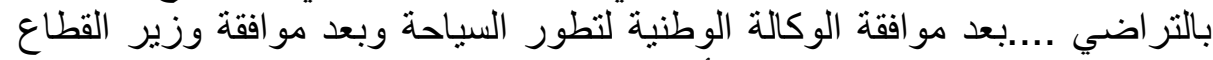

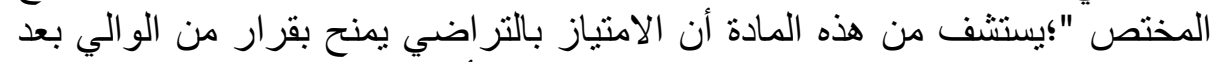

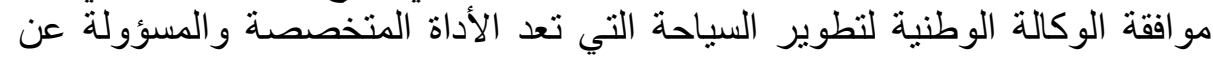

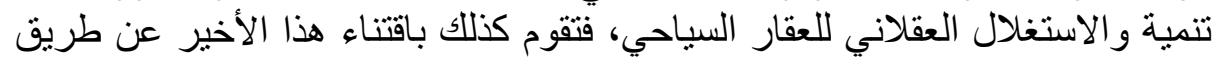
الثفعة وتهيئة الأر اضي لاستقطاب النشاطات السياحية و الفندقية و الحمامات المعدنية،

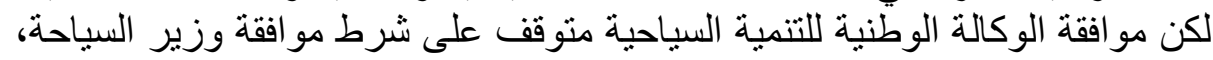

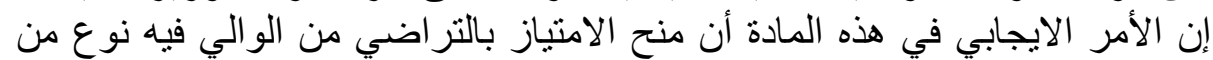

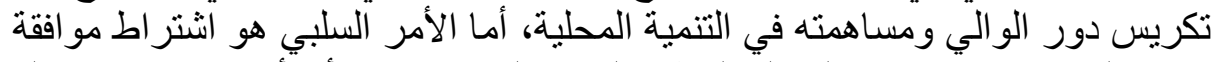

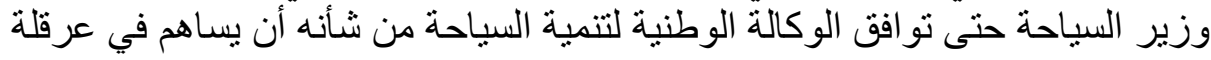

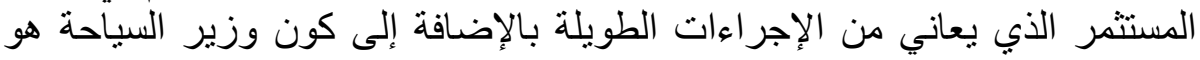

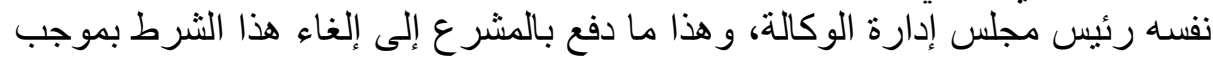

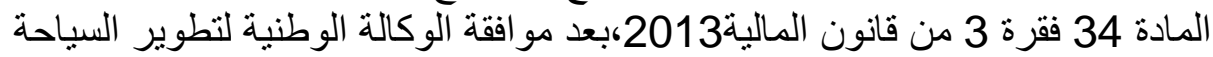

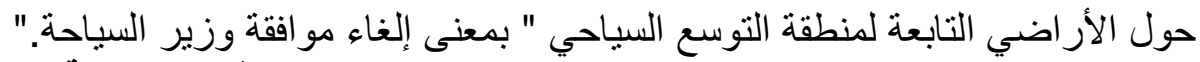

المبحث الثاني: اجراعات منح الامتياز على التعقار السياحي وجليد التياء مانون المالية

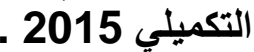

يرتبط الامتياز بالملكية العقارية ارتباطا وثثقا فلم تجعله الدولة محل التنازل من

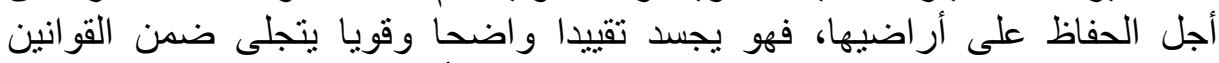

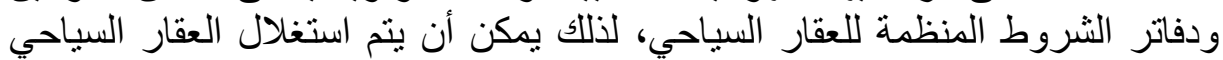

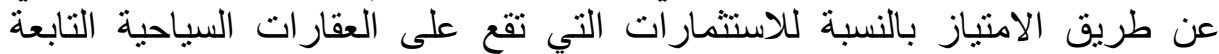

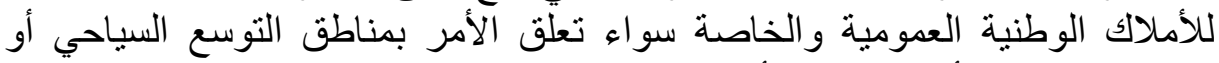

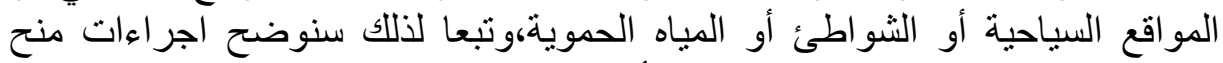

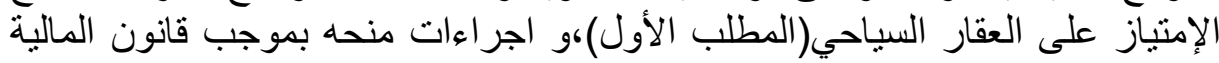
التكميلي 2015 (المطلب الثناني) . 


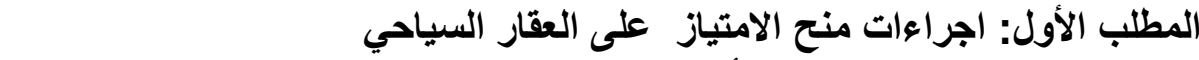

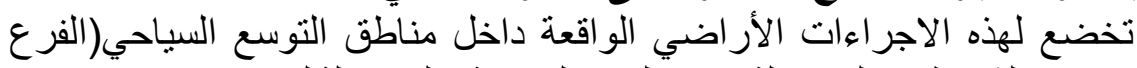

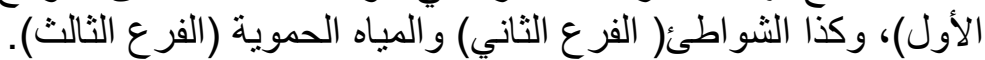
الفرع الأول:اجراءات منح الامتياز على الأراضي الواهي الواهعة داخل مناطق التوسع

قبل صدور الأمر 04/08 منح المشرع الجزائري بموجب القانون 03/03

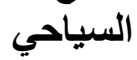

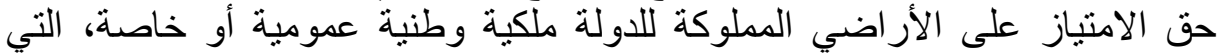

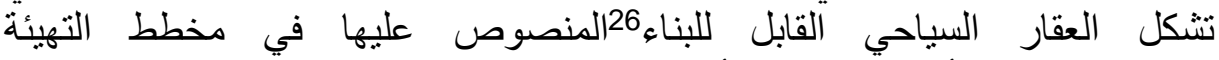
السياحية،واشترط أن تكون تلكئار الأراضي لفائدة استثمار ات محددة في مخطط التهيئة السياحية والمعتمدة طبقا لأحكام القانون

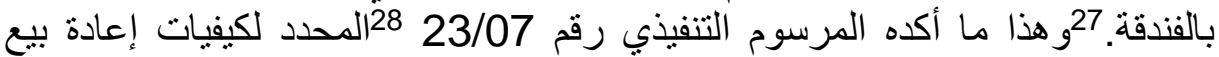

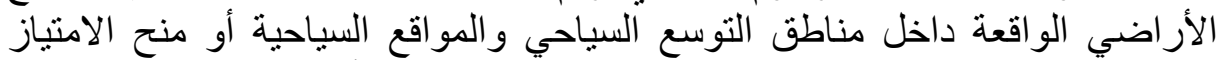

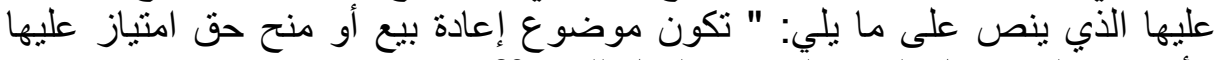
الأراضي التي تشكل العقار السياحي القابل للبناء.

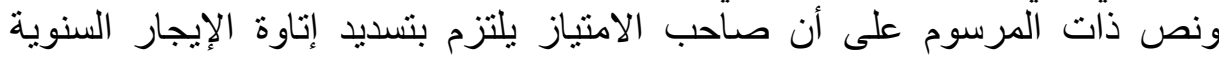

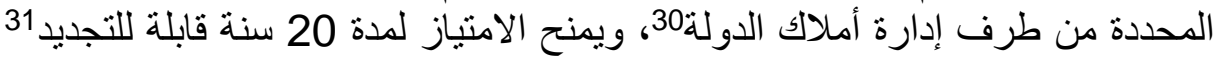

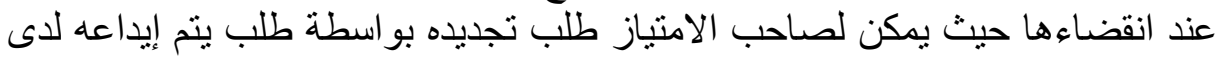

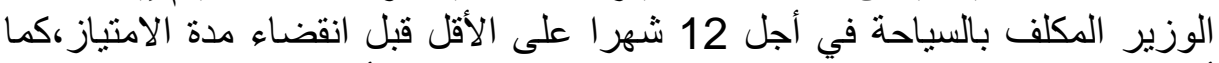

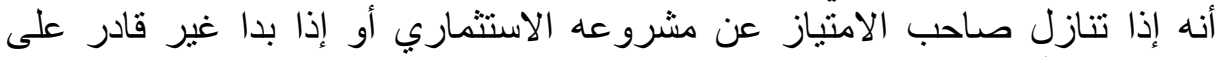

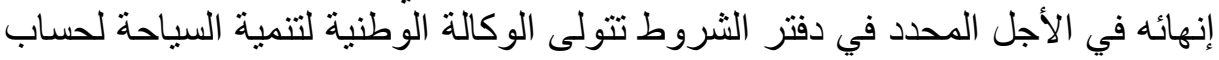

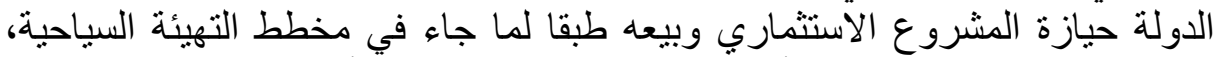

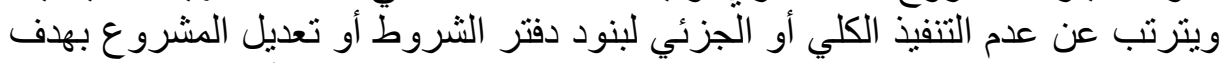

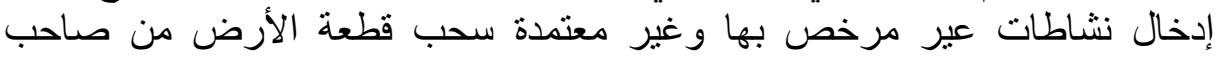

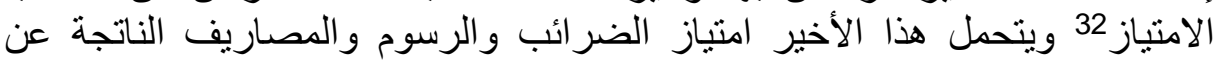

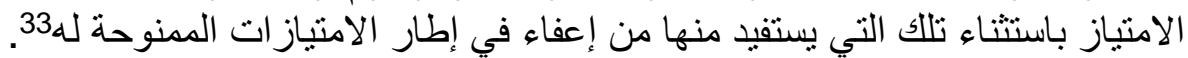

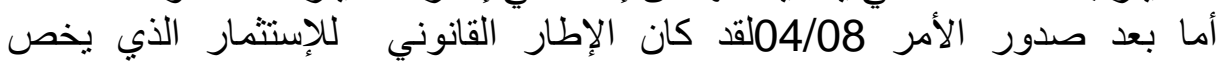

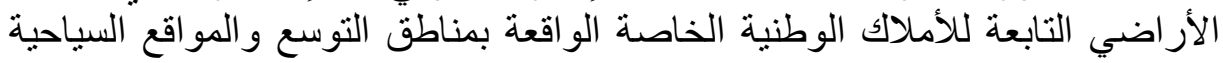

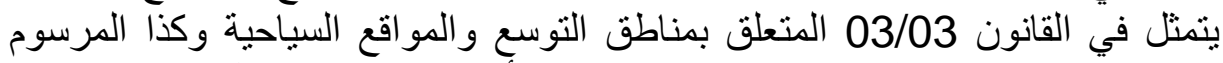

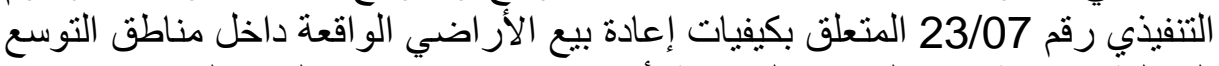

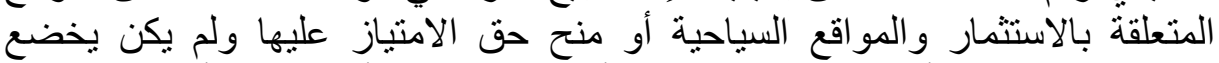

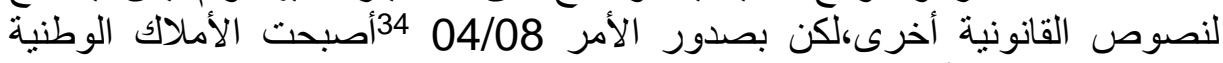

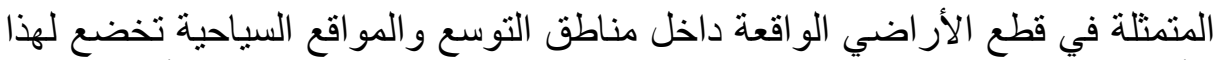

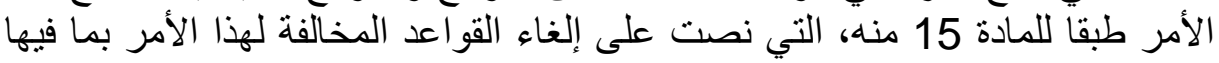

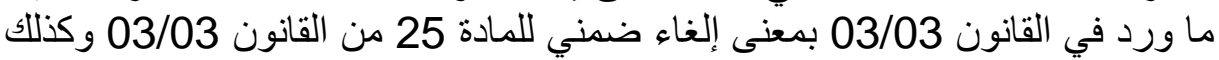

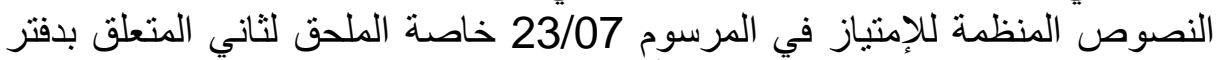

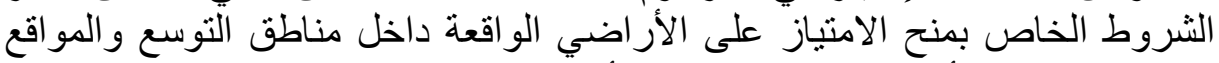

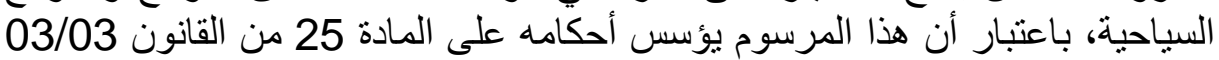

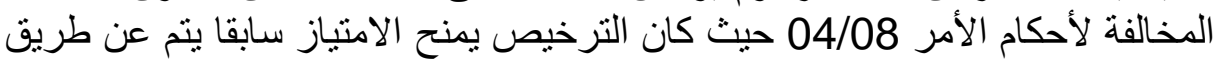

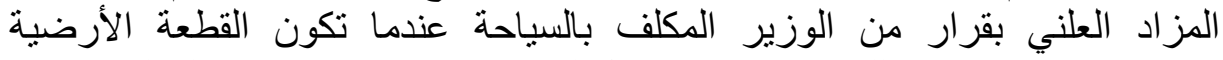

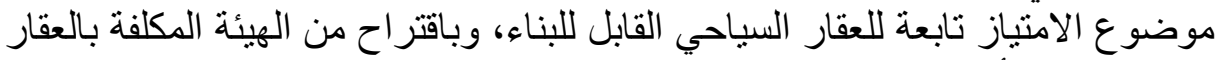

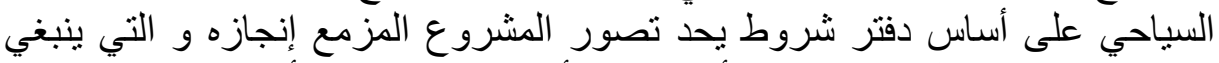

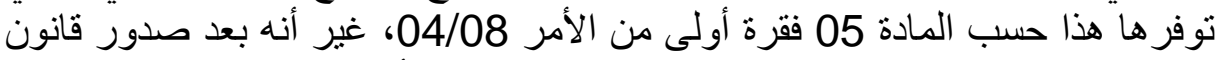

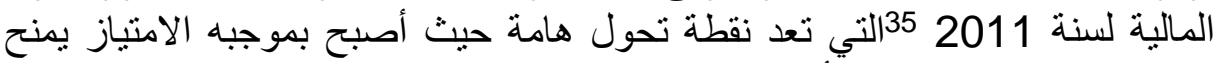
عن طريق التراضي على أساس دفتر شروط وبقرار من الوالي وبعد موافقة الوبة الوكالة 
الوطنية للتنمية السياحية على الأر اضي التابعة لمناطق التوسع السياحي 36.

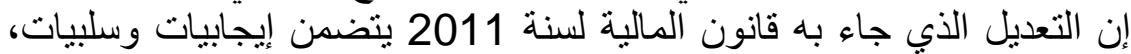

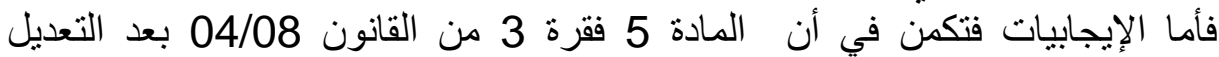

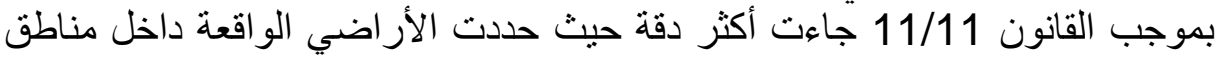

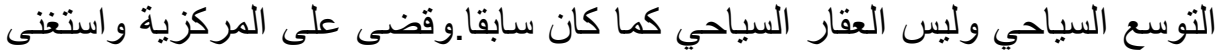

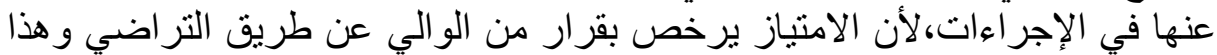

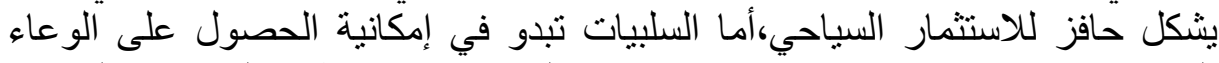

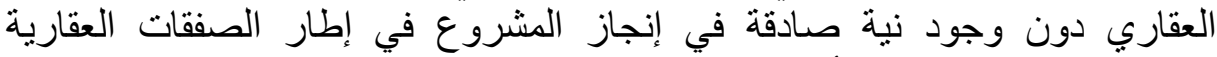
المشبوهة وتغيير وجهة الأرضية الممنوحة عن وجهتها السياحية وقد تم إحصاء في في إنياء

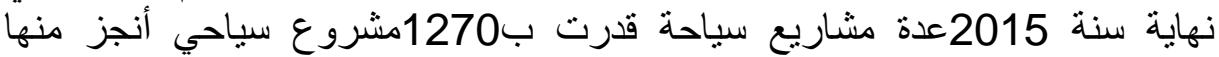
58مشروع فقط تم منحه بموجب عقود امتياز تتعلق بانشاء فنادق ومركبات سياحية و

قرى سياحية

الفرع الثاني:استغلال الثواطئ في إطار عقد الامتياز

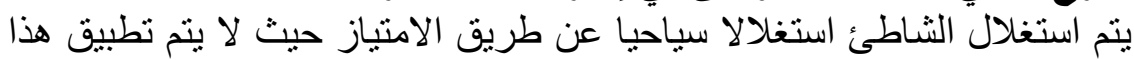

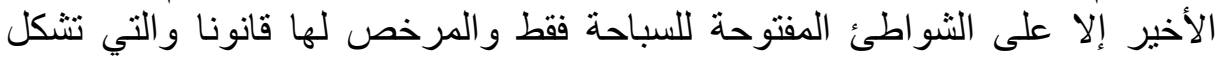
فضاءات للاستجمام والتسلية، حيث نص القانية القانون

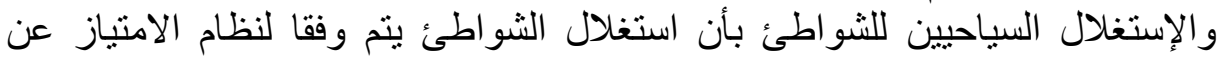

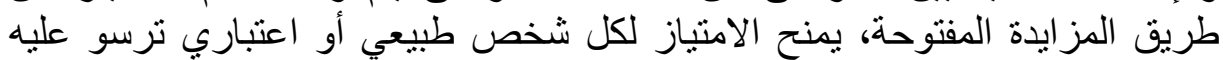

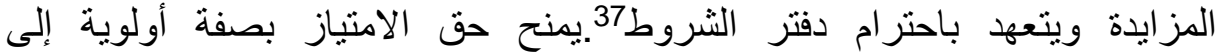

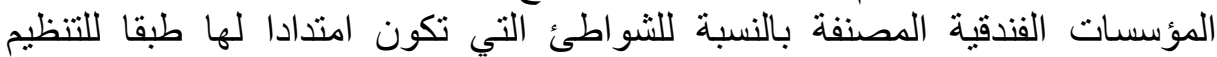

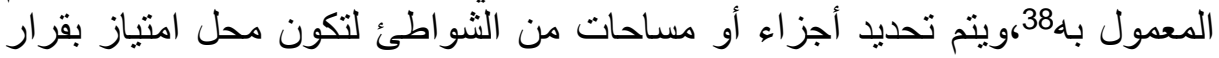

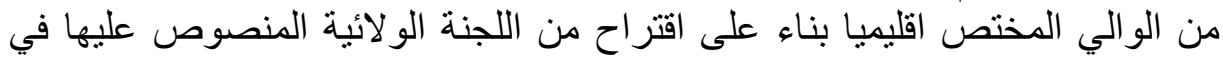

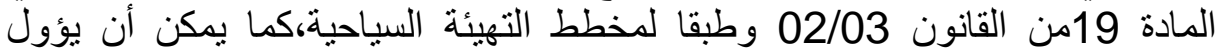

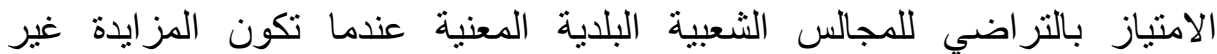

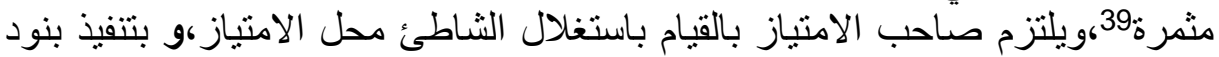

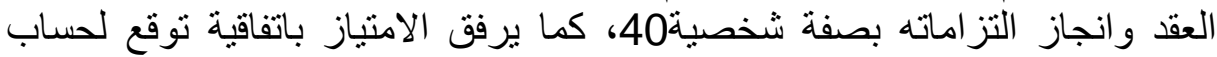

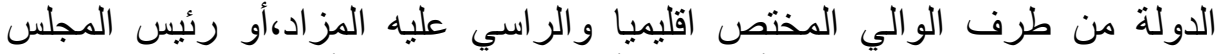

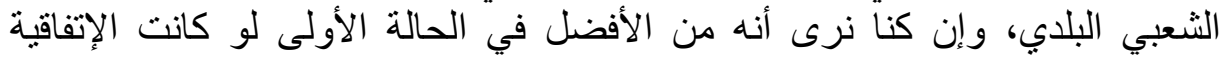

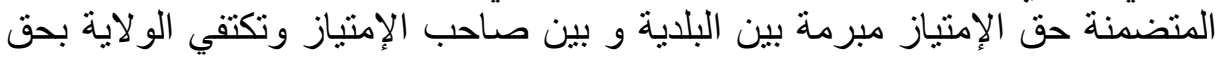

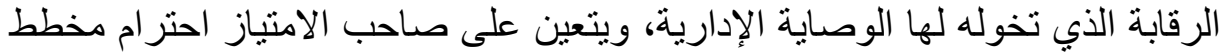
تهيئة الثاطئ الذي يرفق باتفاقية الأنية الامنياز 41.

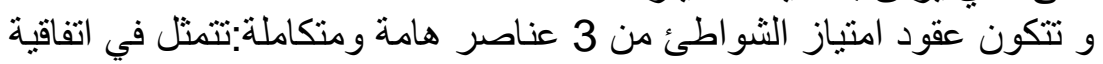

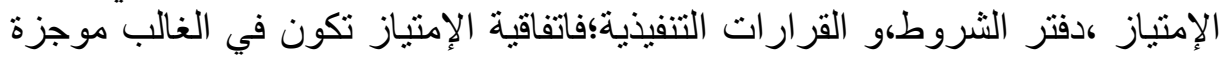

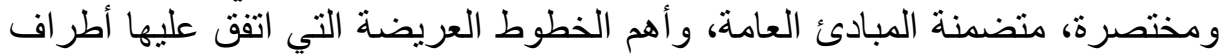

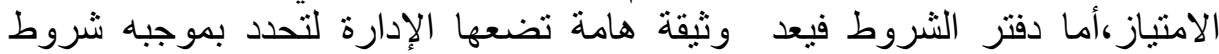

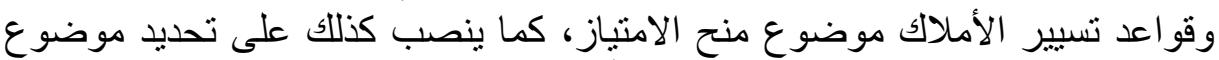

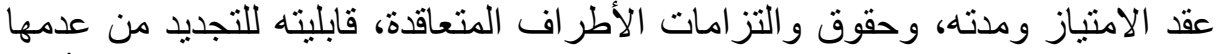

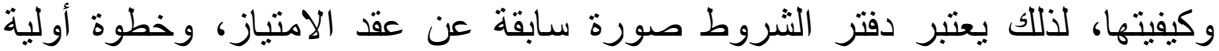

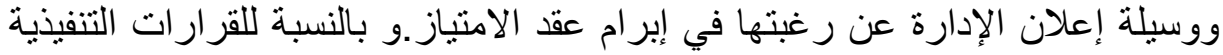

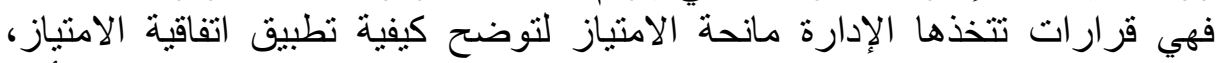

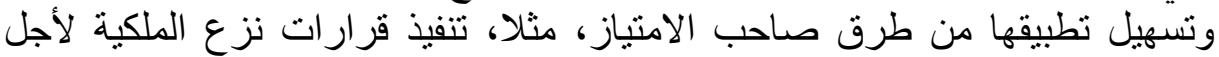

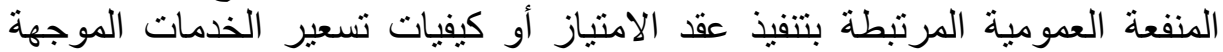
للمنتفعين من المرفق العام. 
إن التنظيم الذي نص عليه القانون 02/03 هو المرسوم التنفيذي رقم

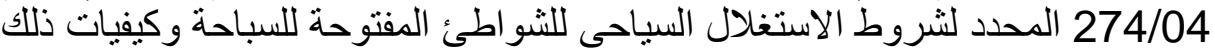

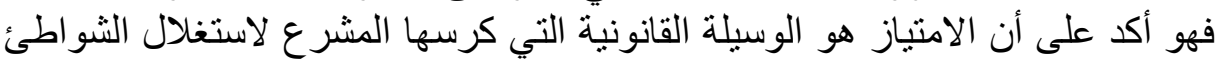

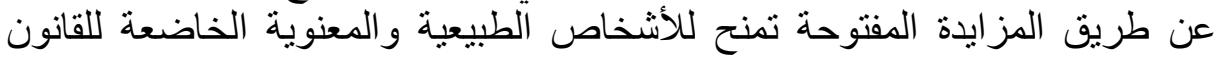

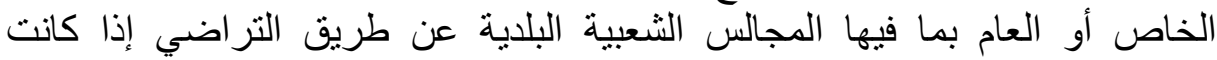

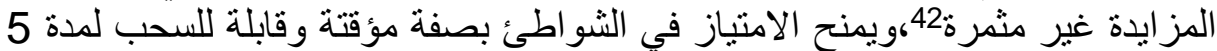

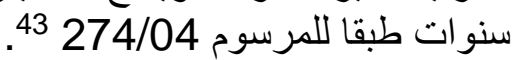

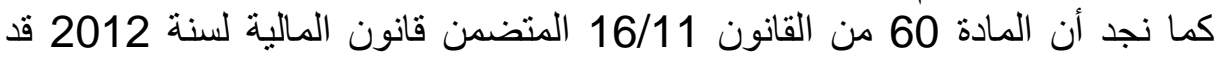

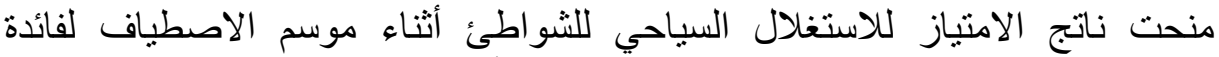

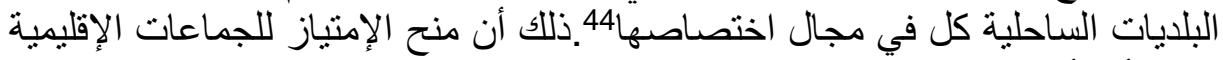

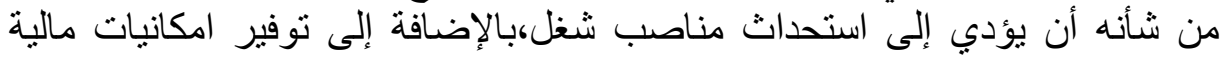

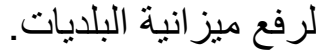

ولقد أكد المسؤول الأول عن قطاع السياحة في الجزائر العاصمة أنه في

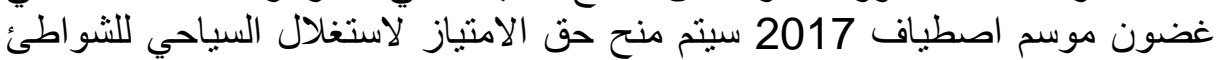

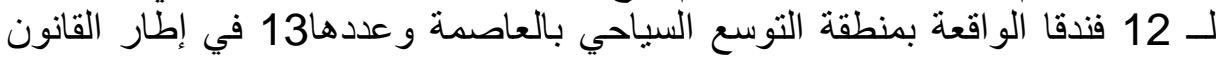

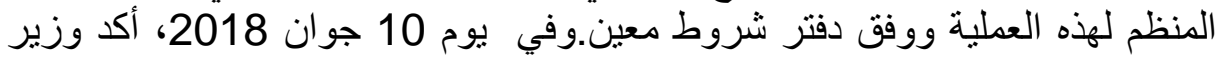

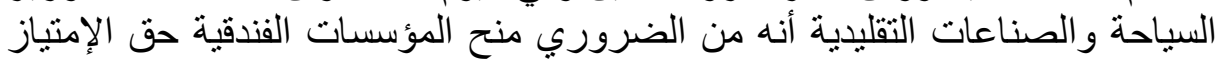

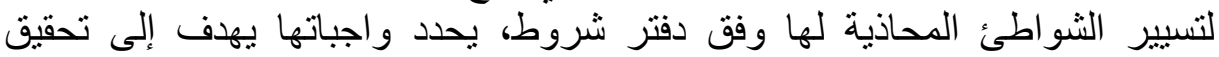

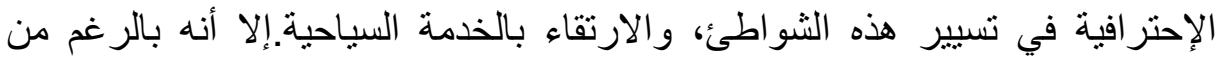

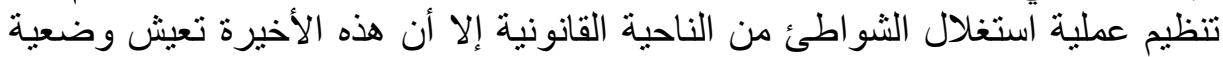

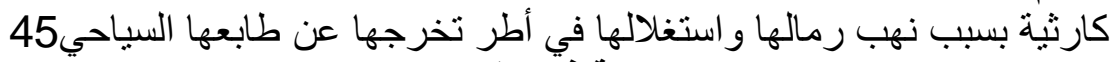
الفرع الثالث:استغلال المياه الحموية في إطار عقد الامتياز

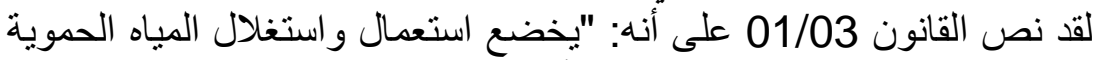
لنظام الامتياز وطبقا لافتر شروط46 وهو هو ما أكده كذلك القانون 12/05 الذي تضمن ما يلي: - nمام ـ بيسلم امتياز استعمال الموارد المائية التابعة للأملاك العمومية الطبيعية للمياه، الذي لئي

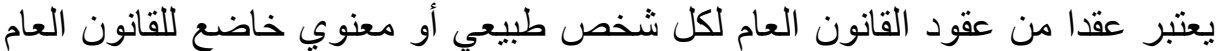

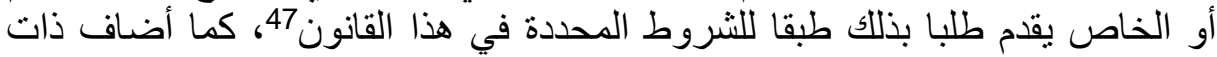

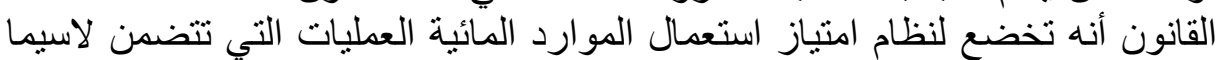

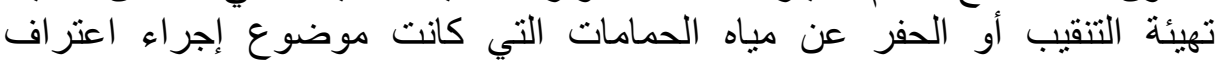

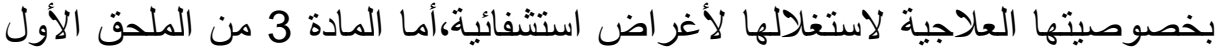

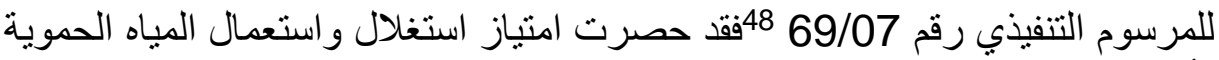

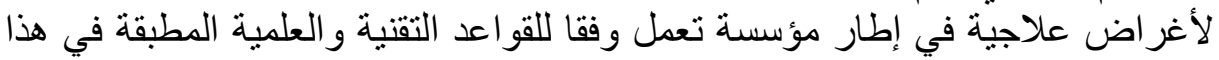

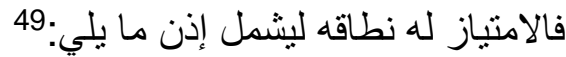

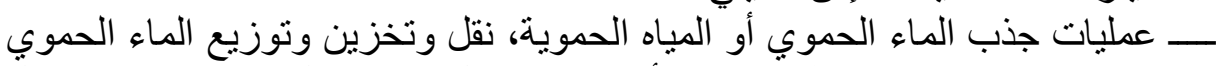

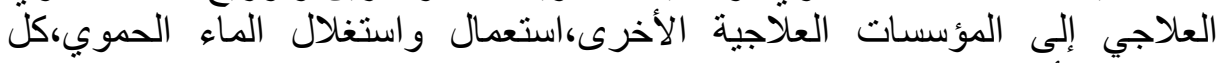
العمليات الأخرى المرتبطة بالامتياز.

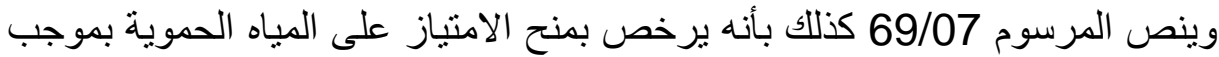

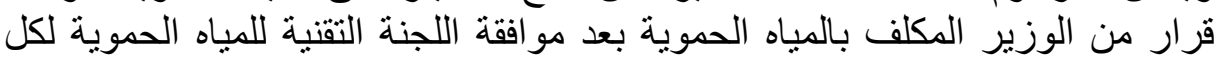

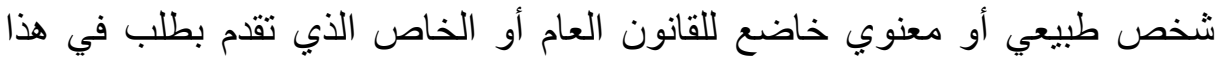

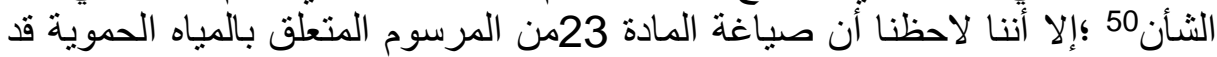

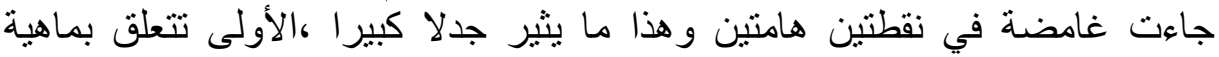

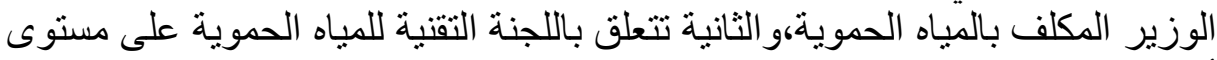

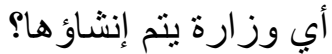


فهل المقصود بالوزير المكلف بالمياه الحموية وزير السياحة و الصناعات التقليدية؟أم

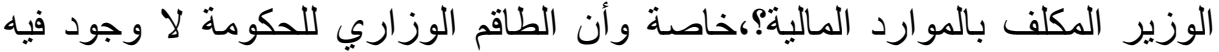

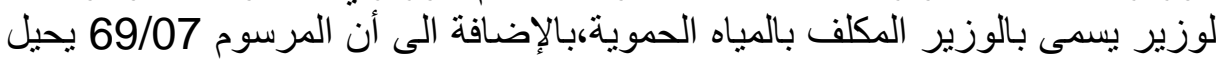

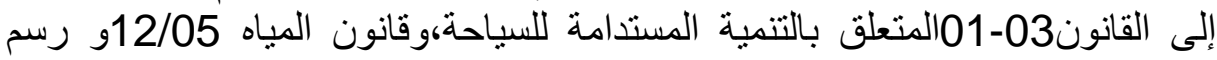

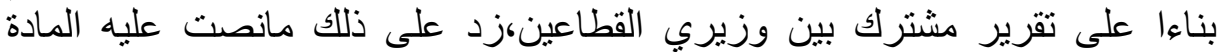

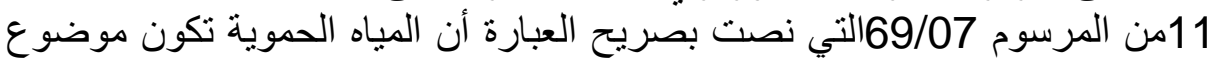

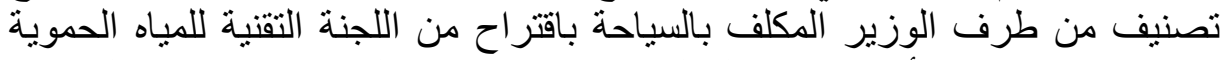

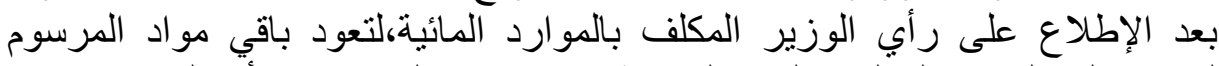

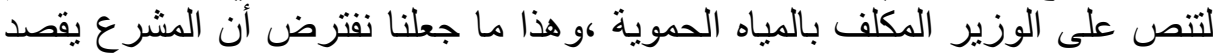

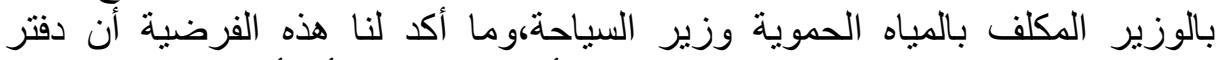

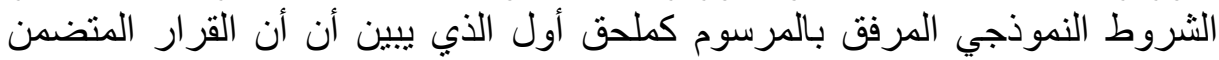

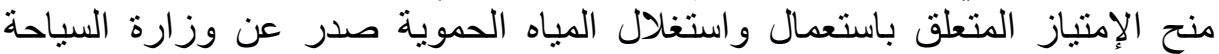
وتمت المصادقة عليه من طرف وزير السياحة، بالإضافة الى أن المياه الحموية تعد العداه

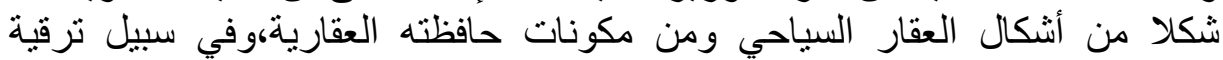

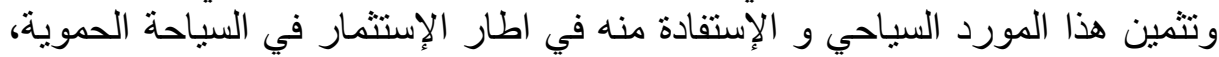

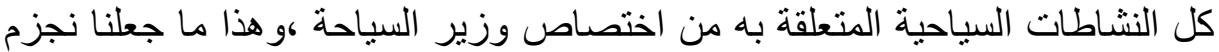

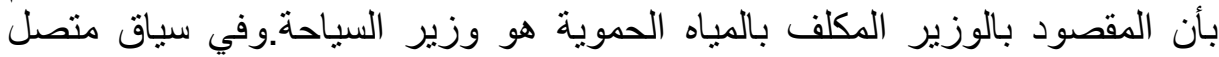

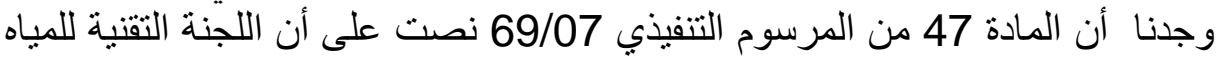

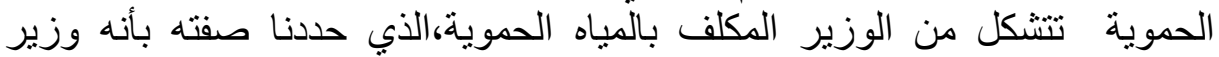

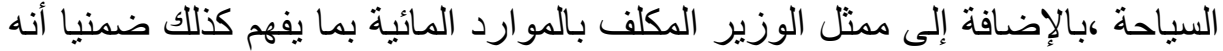

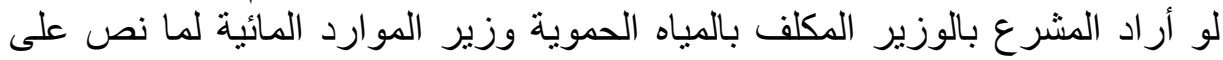

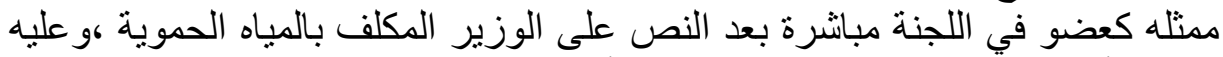

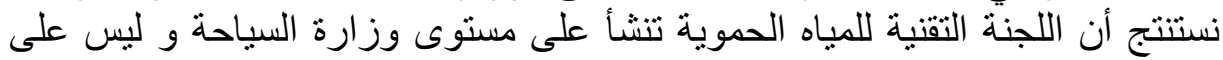
مستوى وزارة الموارد المائية.

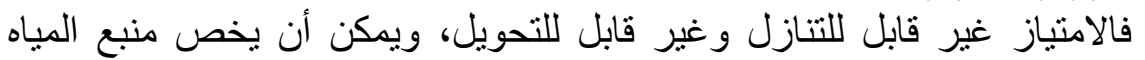

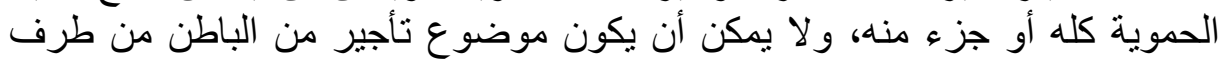
صاحب الامتياز للغير. أولا- شروط منح الامتياز:

لابد أن تتو افر في طالب منح الامتياز الإن الثاز الثروط التالية ليقابل طلبه بالقبول وهي:

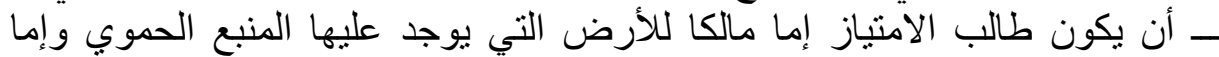

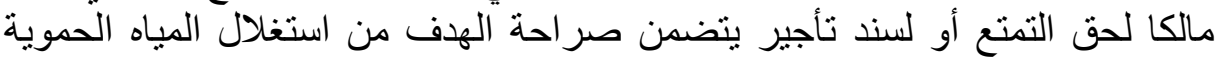

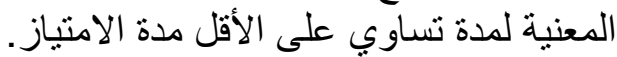

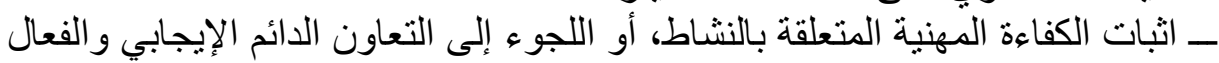
لثخص طبيعي مكلف بتسيير الهياكل العلاجية واستعادة اللياقة البدنية. ـــ توفر الوعاء العقاري المتمثل في الأرض التي ستقام عليها مؤسسة المعالجة بمياه

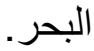
ـ كيازة امتياز أو ترخيص امتياز استعمال مياه البحر 52

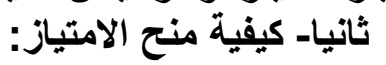

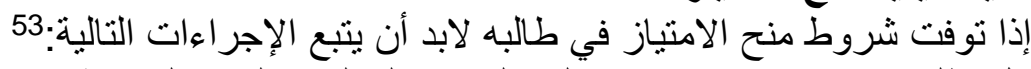

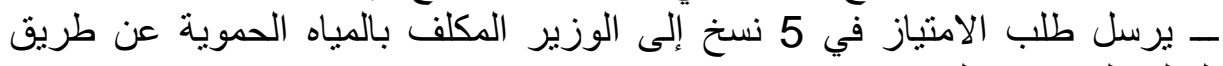
الو الي المختص إقليميا. - يجب على الوالي ارسال هذا الطلب مرفوقا برأيه في أجل لا يتعدى شهرين

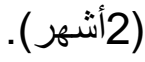




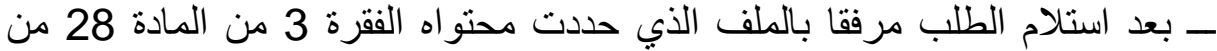
نفس المرسوم ورأي الوالي يقدمه الوزير المكلف بالمياه الحموية للجنة التقنية للمياه

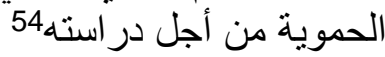

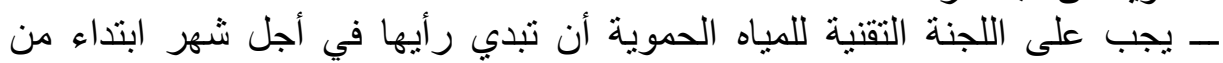

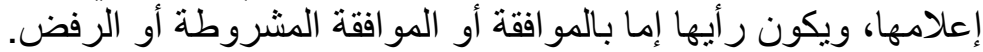

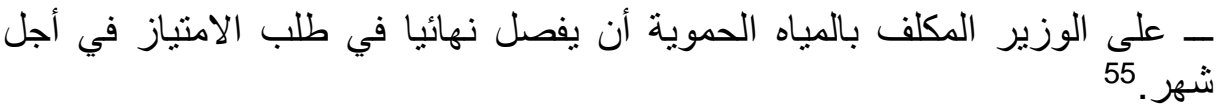

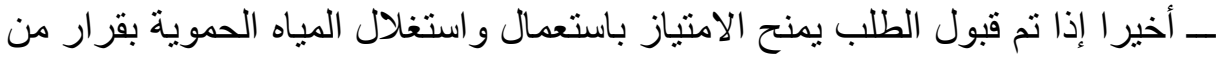

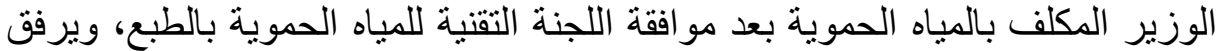

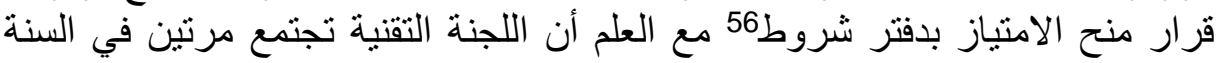

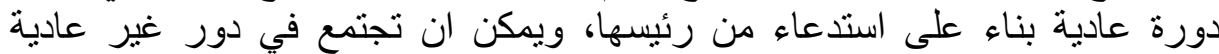

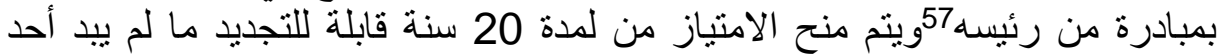

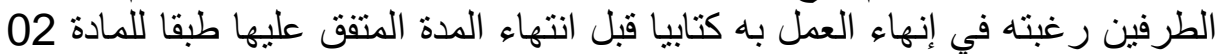

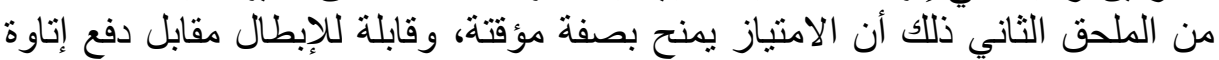

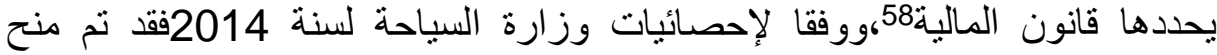

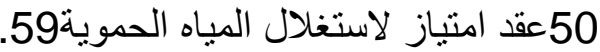

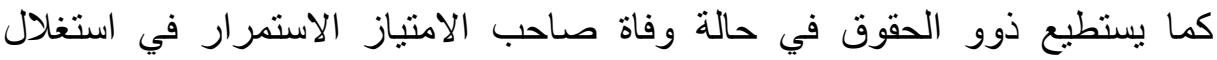
الامتياز بشرط إعلام الوزير المكلف بالمياه الحموية عن طريق الوالي الي المختص إقليميا في أجل لا يتعدى شهرين.

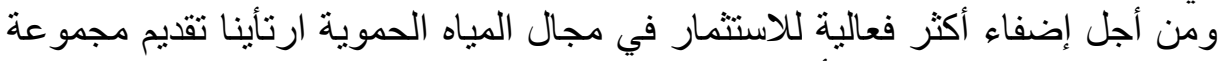

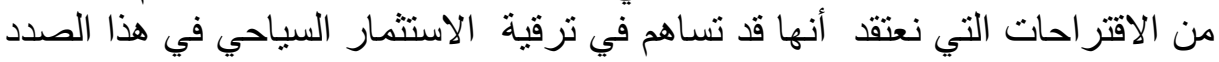

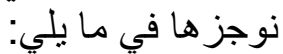
ـ تعديل المادة 22 من المرسوم 69/07 بجعل الامنياز يمنح بقرار من الوالي

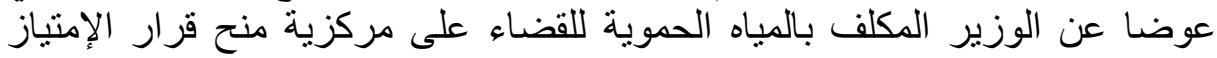

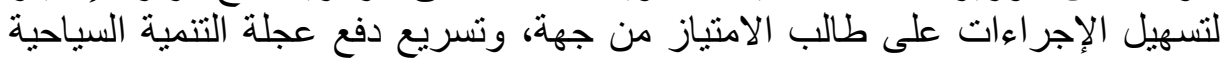
من جهة أخرى،بالإضافةإلى زيادة عد الدورات الات التي تعقدها اللجنة التقنية للمياه

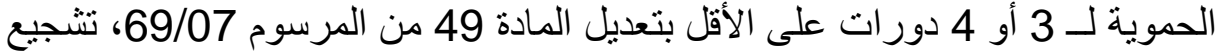

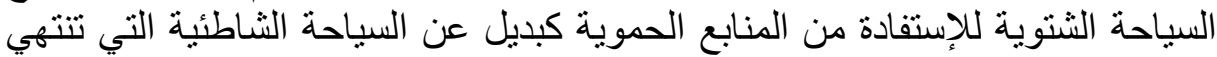

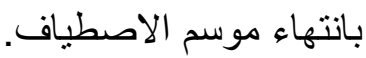
وفعلا تدارك المشرع الجزائري مؤخرا ذللك بموجب المادة 03 من المرسوم التنفيذي 06-16 المؤرخ في 10 يناير 2016 المنضمن تنظيم الإدارة المئرة المركزية لوزارة

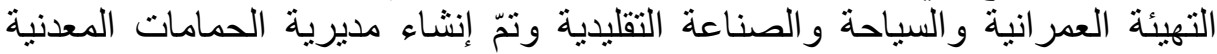

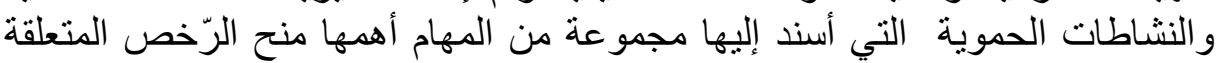

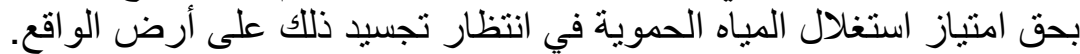

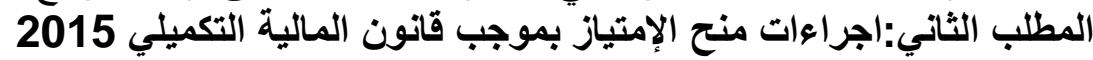

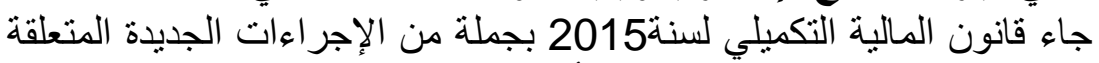

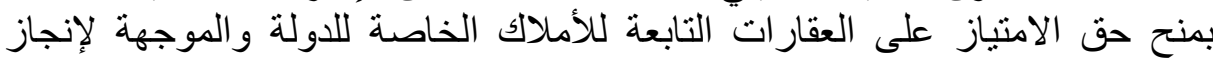

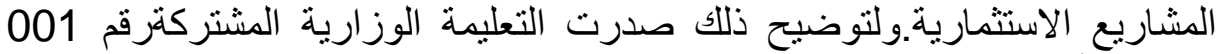

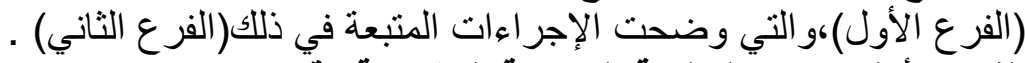

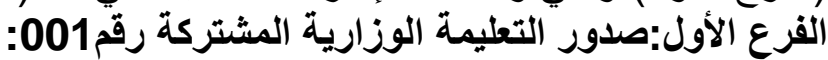

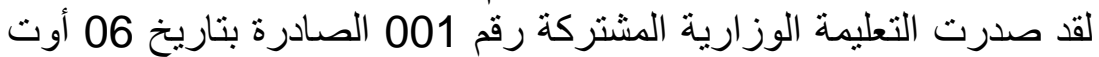

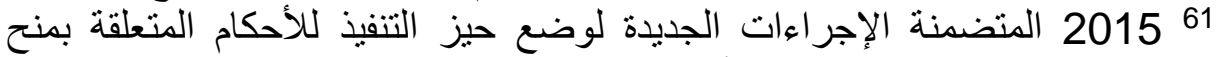

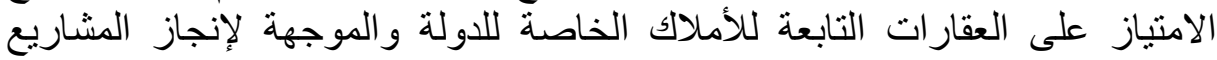

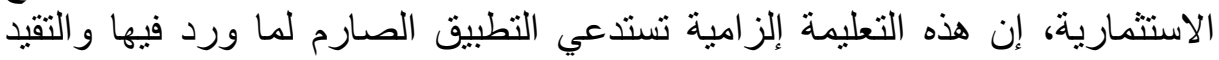
بالإجر اءات الجديدة والآجال المحددة. 
و هذه التعليمة تهدف إلى تحديد كيفيات تطبيق الأحكام الجديدة المتعلقة بمنح حق

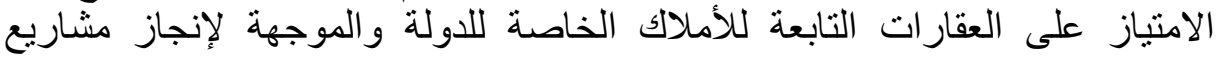

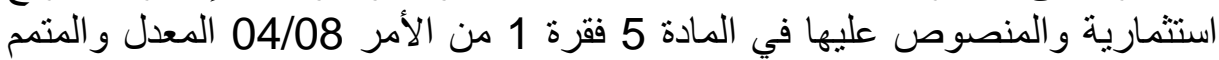

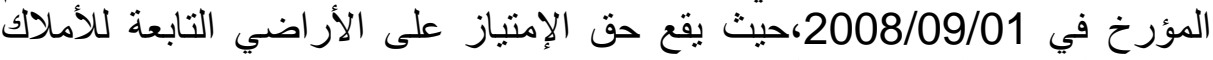

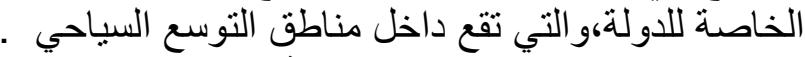

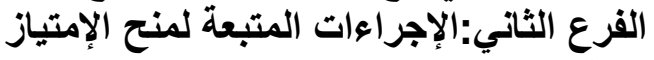

$$
\text { تتمنل هذه الإجر اءعات فيما الأرات الئي: }
$$

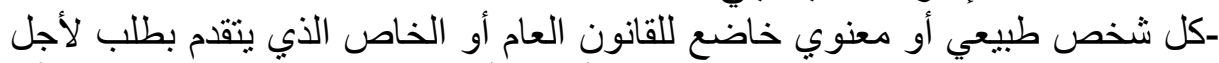

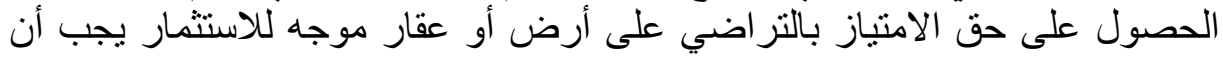

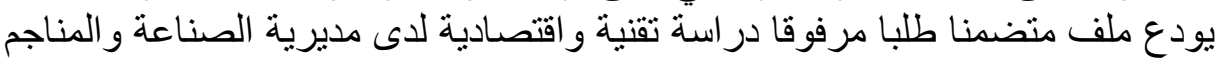
المؤ هلة اقليميا.

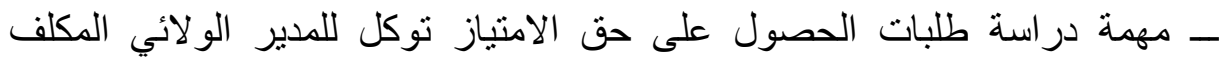

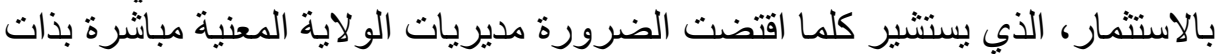

المشروع.

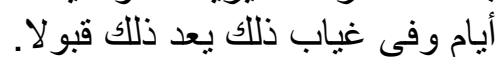

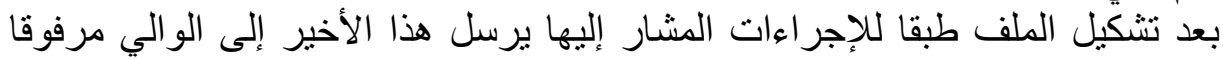

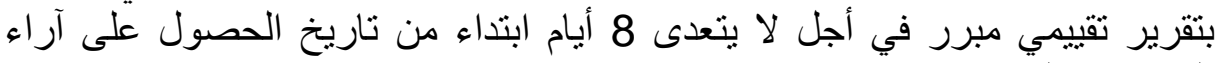
المديريات المعنية. ـ يبت الو الي في الطلب باتخاذ قرار منح الامنياز بالتر اضي.

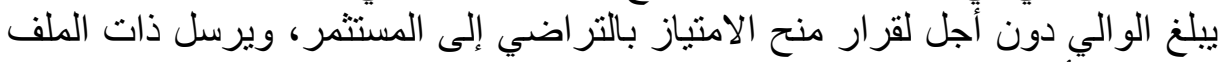

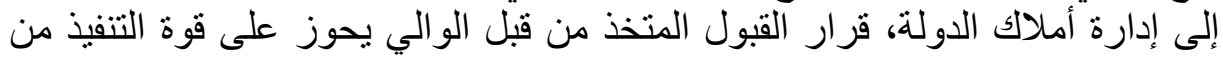
طرف كل مصالح الدولة.

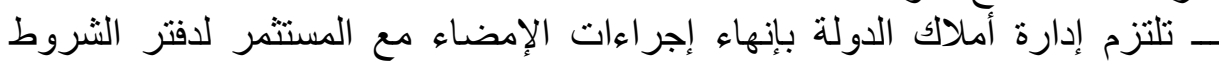

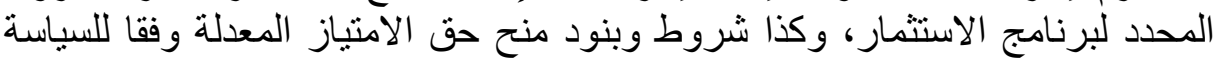

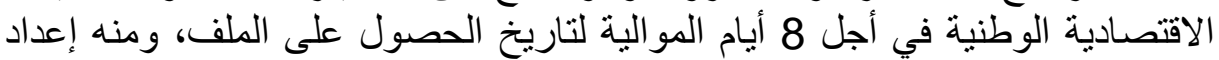

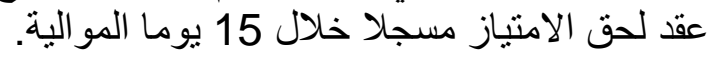

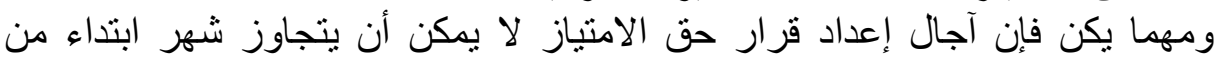

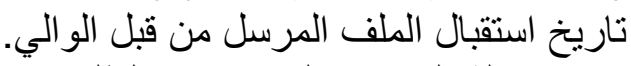

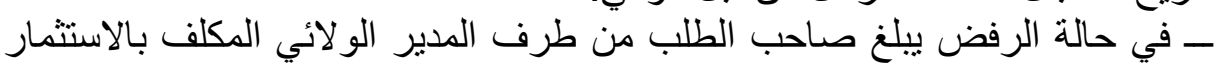
في أجل 15 يوما بموجب تبليغ مبرد. ،وقدر عقود امتياز لاستغلال 51منبعا حمويا من بين 282منبع دموري.

$$
\text { الخاتمة: }
$$

-إن إقرار الدولة لنظام الإمتياز غير القابل للتحويل إلى تنازل كآلية وحيدة لاستغلال

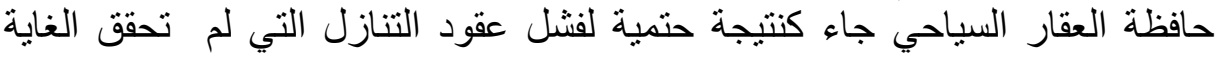

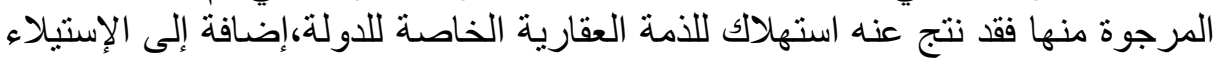

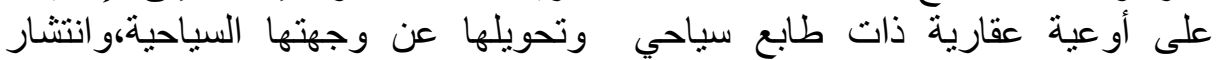
المضاربة فيها. -إن نطاق عقد الإمتياز بالنسبة للعقار السياحي لا يتعلق فقط بالدومين الخاص للإولة الطابة

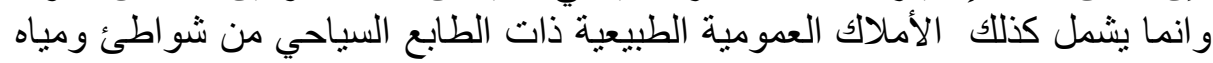

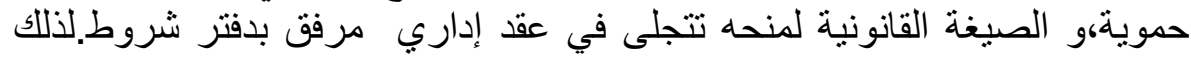


طبيعتة القانو نية مختلطة يحكمه مبدأ سلطان الإر ادة في شقه التعاقدي ويحكمه القانون

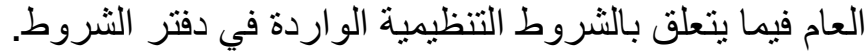

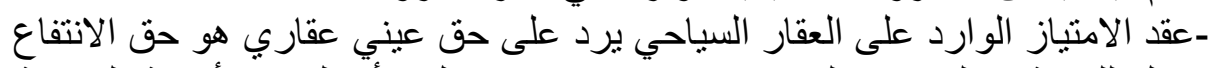

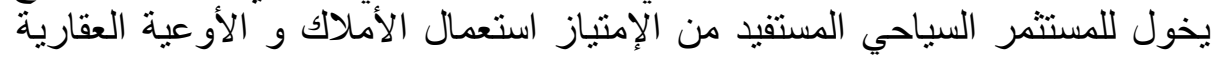
واستغلالها بينما تبقى للاولة محتفظة بملكية الرقبة التبة.

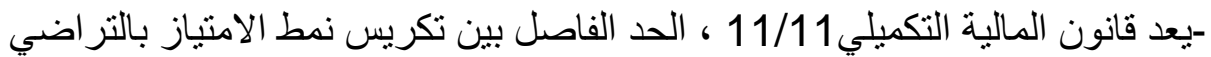

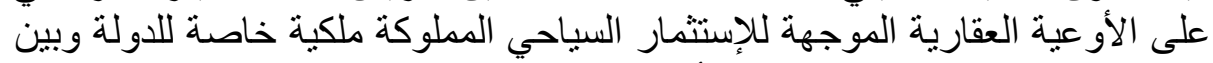

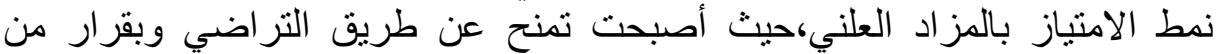

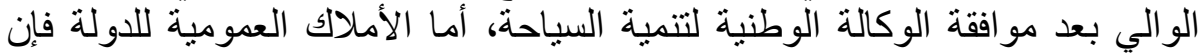

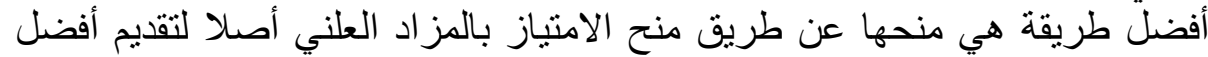

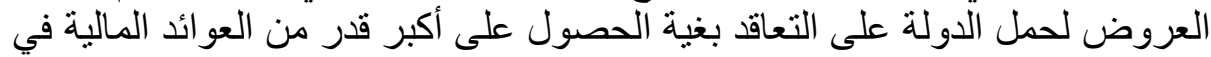
ظل الأزمة الحالية وبصفة استثنائية إذا كان نظام المزاد العاد العلني غير مجدي فنلجاً

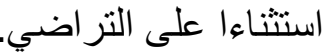

إن تكريس لنظام الإمتياز سيمكن العقار السياحي من تقديم الإضافة الإقتصادية

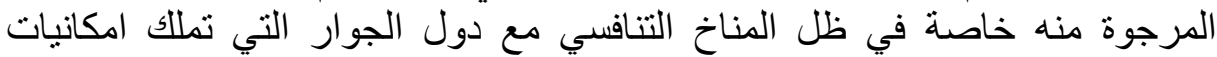

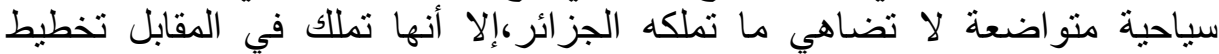
استثمار

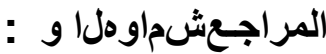

1. المادة 3 من القانون 01-03 مؤرخ في 17 فيفري 2003 المتعلق بالتنمية السياحية،

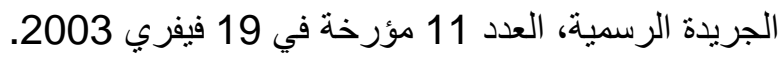

2. عبد الكريم حافظ، الإدارة الفندقية والسياحية، دار أسامة للنشر والتوزي فئية، الطبعة

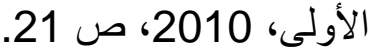

3. القانون 11/99، مؤرخ في 1999/01/06 المحدد للقواعد العامة المتعلقة بالفندقة، الجريدة الرسمية، العدد2، مؤرخة في 4. المرسوم التنفيذي رقم 46/2000، الذي يعرف المؤسسات الفندقية ويحدد تنظيمها وسير ها وكيفية استغلالها، جريدة رسمية، عدد 10، مؤرخة في 05 مارس 05 مانس

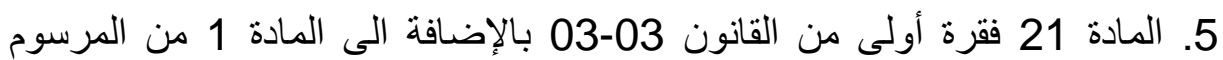
التنفيذي 385/06 مؤرخ في 28 أكتوبر 2006 المتعلق بممارسة الوكالة الوطنية

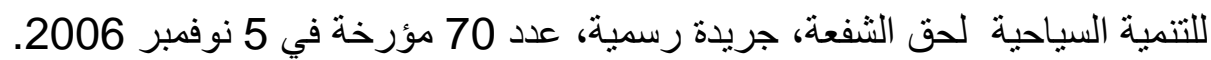
6. المادة 22 فقرة 2 من القانون 03-03 السابق الذكر.

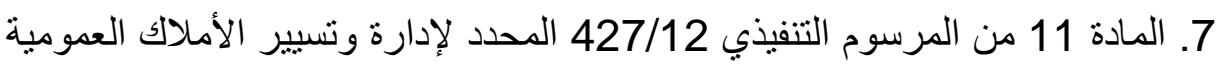
و الخاصة التابعة للاولة، جريدة رسمية عدد 69، مؤرخة في 2012/12/19.

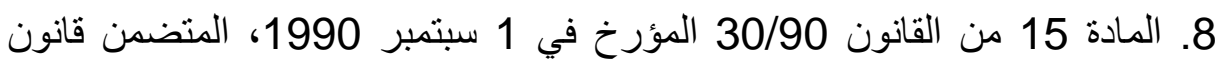

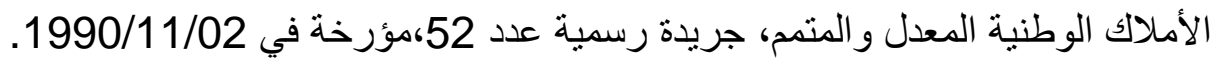
9. المادة 26 من القانون 02/02 المتعلق بحماية الساحل وتتميته، مؤرخ في في 5 فيفري 2002، الجريدة الرسمية عدد 10.

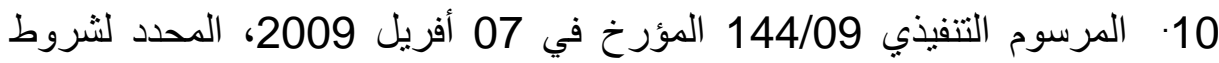
اعداد مخطط تهيئة الثاطئ، ومحتو اه وكيفيات تتفيذه، جريدة رسمية عدد 21، مؤرخة في 8 أفريل 2009. 
11. الحمامات المعدنية، الديوان الوطني للسياحة، الجزائر، 2009، ص 15.

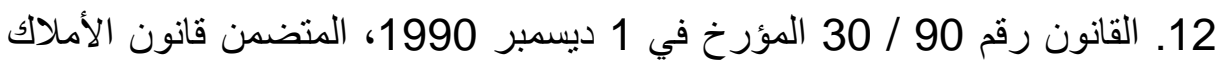
الوطنية المعدل و المتمح.

13. القانون 12/05 المتضمن قانون المياه المؤرخ في 04 أوت 2005، جوند جريدة رسمية عدد 60، مؤرخة في سبتمبر 2005.

14.AZOUZ. KERDOUN(2000), l'envirenement et developpement duralle (ennjeux et défis) édition published, paris 2000,p 110.

15.Cheriekofe Alain- Serge: droit des services public $1^{\text {er }}$ édition put, Paris1991,p343.

16. سليمان الطماوي، الأسس العامة للعقود الإدارية، الطبعة الأولى، دار الفكر

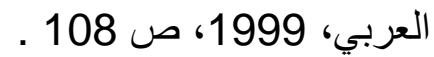

17. ناصر لباد، الوجيز في القانون الإداري، الطبعة الأولى، منشورات لباد، الجزائر،

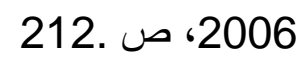
18. مجلس الدولة، قرار رقم 2006، 11950، المؤرخ في 09 مارس 2004، قضية شركة

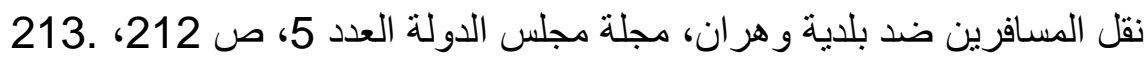

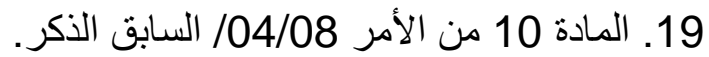

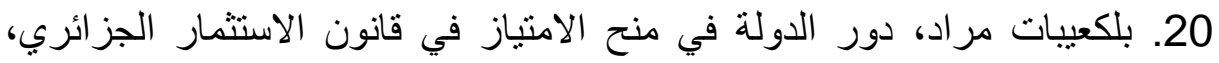

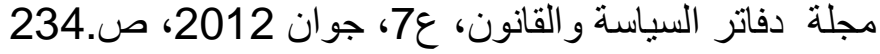

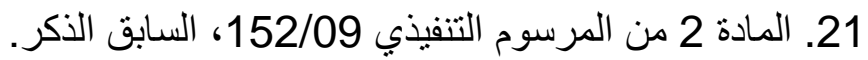

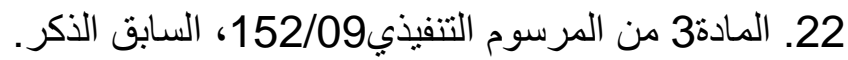

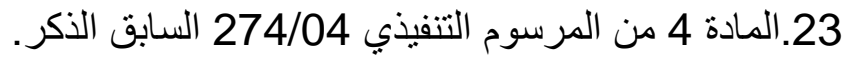

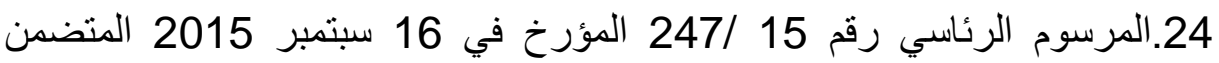
تنظيم الصفقات العمومية وتفويض المرفق العام الذي ألغى المرسوم الرئي الرئاسي رقم 236/10 المتضمن تنظيم الصفقات العمومية . 25. المرسوم التنفيذي رقم 98-70، المتضمن انشاء الوكالة الوطنية لتنمية السياحة وتحديد قانونها الأساسي، الجريدة الرسمية، عدد 11 مؤرخة في 1 مارس .1998

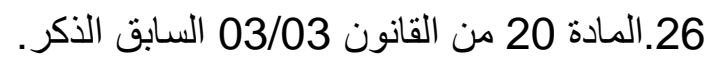

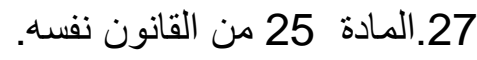

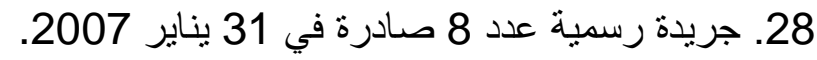

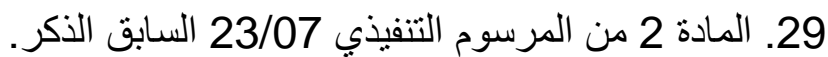

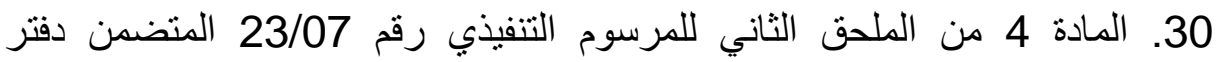
الثروط النموذجي المتعلق بمنح امتياز على الأراضي الواقعة داخل مناطق التوسع السياحي و المو اقع السياحية. 31. المادة 5 من نفس الملحق الثاني من المرسوم التنفيذي رقم 23/07 السابق الذكر.

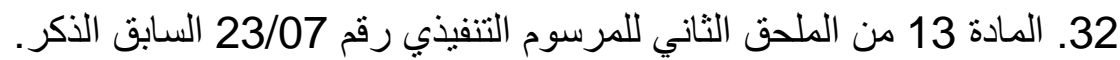
33. المادة 17 من الملحق السابق الذكر. 
34. الأمر 04/08 المؤرخ في 1سبتمبر 2008، المحدد لنروط وكيفيات منح

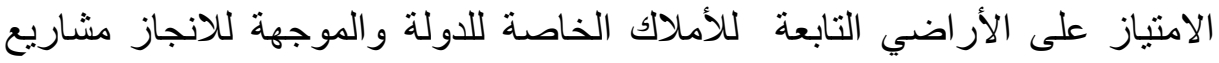

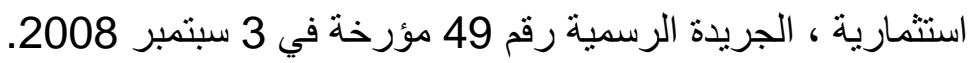

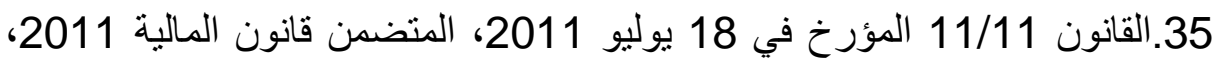
الجريدة الرسمية عدد 40، مؤرخة في 20 يوليو .2011 36. المادتين 3 و 5 فقرة 3 من القانون 04/08، بعد بدهد التعديل بموجب القانون 11/11 ، السابق الذكر.

37. إحصائيات وز ارة التهيئة العمر انية والسياحة و الصناعات التقليديةلسنة.2015 38. المواد من 22 ـ إلى 27من القانون 02/03 السابق الذكر.

39. République Algérienne démocratique et populaire-Les concessions des plages, guide du domaine public maritime,. Octobre 2004 page 45.

40.B- Rahal(1994), la concession de service en droit algerien, Revue IDRA, n 01-1994.p 30.

41. أعمر يحياوي، نظرية المال العام، دار هومة، الجزائر، 2005، الطبعة 3، ص 88. 87

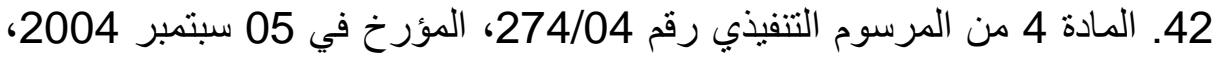
الذي يحدد شروط الاستغلال السياحي للشواطئ المفتوحة للسباحة وكيفيات ذللك،

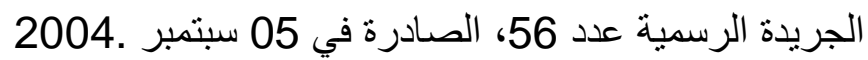

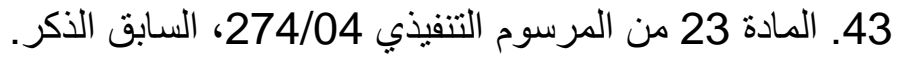
44 قانون 16/11 المتضمن قانون المالية 2012، الجريدة الرسمية العدد 72 ، مؤرخة في 29 ديسمبر 2011.

45. Mourad Bouchama, Jijel dilapidation du foncier touristique -liberté Algérie Mardi 25 juillet 2006,http://www.Jijel-dz.info

46.المواد 77،76، 78 من القانون 12/05 المؤرخ في 04 غشت

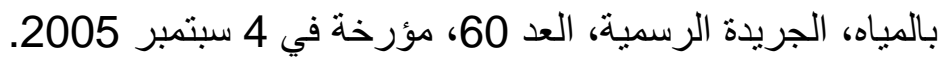

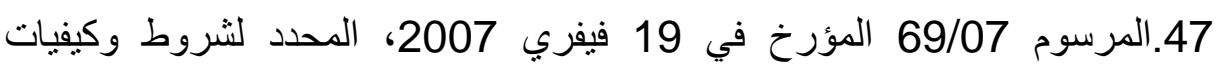
استعمال واستغلال المياه الحموية، الجريدة الرسمية العدد 13 مؤرخة في 21 فئري فيفري .2007 48.المادة 3 من الملحق الثاني للمرسوم التنفيذي رقم 69/07، المتضمن دفتر الثروط النموذجي المتعلق بالحقوق والواجبات المرتبطة بامتياز استعمال واستغلال المياه الحموية. 49.المادة 23 من المرسوم التتفيذي رقم 69/07. 50.المادة 24 من ذات المادة المرسوم. 51.المادة 25 من ذادة ذات المر دات المرسوم.

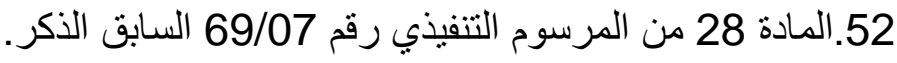
53.المادة 29 من المرسوم نف المرسوم نفسه. 


$$
\text { 56 54. 54.المادة } 30 \text { من المادة } 43 \text { من المرسوم نفسه. }
$$

57.المادة 6 من الملحق الأول للمرسئل المرسوم التنفيذي رقم 69/07، المنضمن قرار منح امتياز استعمال واستغلال المياه الحموية.

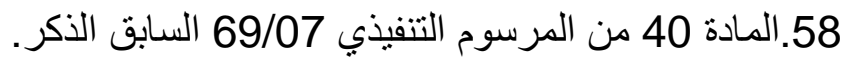

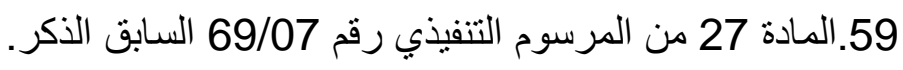

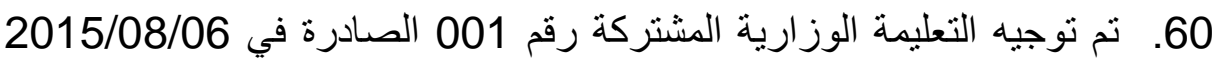

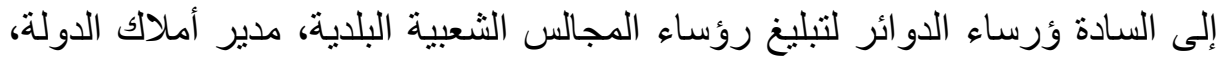

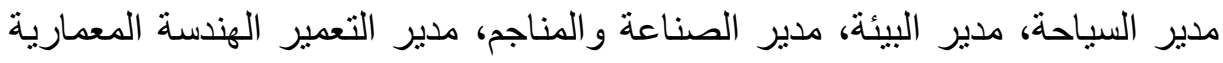
و البناء، مدير المصالح الفلاحية، محافظ الغابات، مدير الصيد البحري. البعري. 